\title{
Um Novo Modelo para Cálculo de Probabilidade de Paternidade - Concepção e Implementação
}

Fábio Nakano

7 de Fevereiro de 2007 


\section{Conteúdo}

1 Agradecimentos $\quad 5$

2 Introdução $\quad 5$

3 Biologia - conceitos básicos e revisão histórica dirigida $\quad 8$

4 Probabilidade e Estatística - conceitos e ferramentas utiliza$\begin{array}{lr}\text { dos neste trabalho } & 26\end{array}$

4.1 Conceitos . . . . . . . . . . . . . . . . . 26

4.2 Redes Bayesianas . . . . . . . . . . . . . . . . . . 29

4.3 Combinação dos resultados de vários experimentos . . . . . . 31

4.4 Teste de Hipóteses . . . . . . . . . . . . . . . . . . . . . 37

5 Modelo $\quad 46$

5.1 Modelo Proposto . . . . . . . . . . . . . . . . . . . . . 46

5.2 Modelo de Referência . . . . . . . . . . . . . . . . . . 52

5.3 Relação entre o modelo proposto e o de referência . . . . . . . 55

5.4 Exemplo onde há diferença entre o modelo proposto e o modelo de referência .................. . . 55

6 Implementação $\quad 60$

6.1 Definição da Linguagem . . . . . . . . . . . . . . . . . . . . 62

6.1.1 Definições Léxicas e Sintáticas . . . . . . . . . . . . . 65

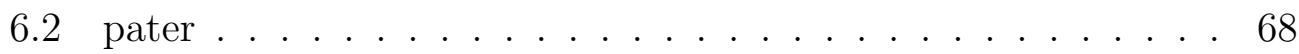

6.3 sh script . . . . . . . . . . . . . . . . . . . . . 70

6.4 calcProb . . . . . . . . . . . . . . . . . 74

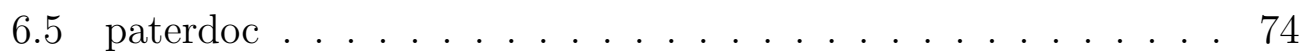

6.6 bifdoc . . . . . . . . . . . . . . . . . . . . 75

6.7 Teste do equilíbrio de Hardy-Weinberg . . . . . . . . . . 75

$\begin{array}{lll}7 & \text { Comentários Finais } & 78\end{array}$

\section{Lista de Tabelas}

1 Cruzamento entre homozigotos . . . . . . . . . . . 9

2 Cruzamento entre heterozigotos . . . . . . . . . . . . 9 
$3 \operatorname{Pr}($ gen_filho $\mid$ gen_pai, gen_mae) $\ldots \ldots \ldots \ldots . \ldots . \ldots 34$

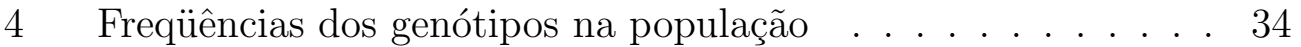

5 Probabilidade Conjunta para Trio . . . . . . . . . . . . . 35

6 Inversão da probabilidade - Probabilidade do genótipo do pai dado genótipo do filho $=\left[A_{1} A_{1}\right] \ldots \ldots \ldots$

$7 \mathrm{p}$ (gen_filho $\mid$ gen_pai, gen_mae) . . . . . . . . . . 36

$8 \quad \operatorname{Pr}$ (pai presumido $\ldots \ldots \ldots \ldots \ldots \ldots \ldots$

9 verdadeiro . . . . . . . . . . . . . . . . . . . . . 38

$10 \operatorname{Pr}($ eh igual $) \ldots \ldots \ldots \ldots$

$11 \quad \operatorname{Pr}(f . g t)$ e $\operatorname{Pr}(m . g t) \ldots \ldots \ldots \ldots \ldots$

$12 \operatorname{Pr}($ c.omg $\mid$ m.gt $)$ e $\operatorname{Pr}($ c.opg $\mid$ c.father.gt $) \ldots \ldots \ldots \ldots . . .48$

$13 \operatorname{Pr}($ c.mg.mutation $\mid$ c.omg $)$ e $\operatorname{Pr}($ c.pg.mutation|c.opg $) \quad \ldots \ldots 48$

$14 \operatorname{Pr}($ c.gt|c.pg.mutation, c.mg.mutation $) \ldots \ldots \ldots$

$15 \operatorname{Pr}($ c.father.gt|f.gt,Test.f.is.father $) \ldots \ldots \ldots \ldots$

$16 \operatorname{Pr}($ Test.f.is.father $) \ldots \ldots \ldots \ldots \ldots$

$17 \mathrm{p}(\mathrm{gt} \mid \mathrm{mg}, \mathrm{pg})$ - Genótipo do Indivíduo. . . . . . . . . . 52

$18 \operatorname{Pr}(\mathrm{pg})$ - Freqüências dos alelos na população. . . . . . . . . 53

19 Contagem de indivíduos por genótipo . . . . . . . . . . 56

20 Freqüências genotípicas . . . . . . . . . . . . . . 5 56

21 Probabilidade de paternidade obtida usando o modelo proposto 56

\section{Lista de Figuras}

1 Exemplo de heredograma - Vínculo consangüíneo $\ldots \ldots \ldots 7$

2 meiose e mitose . . . . . . . . . . . . . . . . . 12

3 Experimento de Griffith - Princípio Transformador . . . . . . 14

4 Experimento Avery, McLeod, McCarty - DNA é o princípio transformador . . . . . . . . . . . . . . . . . 15

5 Estrutura do DNA . . . . . . . . . . . . . . 16

6 DNA Polimerase . . . . . . . . . . . . . . . 17

7 Reação em Cadeia de Polimerase . . . . . . . . . . . . . . . . 19

8 Eletroforese . . . . . . . . . . . . . . . . . 20

9 Gel para um marcador . . . . . . . . . . . . . . . . . . 21

10 cromatograma de seqüenciamento . . . . . . . . . . . . 22

11 Rede Bayesiana de um Trio (pai, mãe e filho) . . . . . . . . . 30

12 Teste da hipótese de que o pai presumido é o pai verdadeiro. . 38

13 Teste conjunto de paternidade e maternidade . . . . . . . . . 40 
14 Densidade para HWE dois alelos . . . . . . . . . . . . 42

15 Espaço paramétrico, hipótese e conjunto de máxima surpresa relativa para o teste do equilíbrio de Hardy-Weinberg . . . . . 43

16 Trio com mutação . . . . . . . . . . . . . . . . . . . 47

17 Trio com teste da hipótese de paternidade . . . . . . . . . 47

18 Representação do Indivíduo. . . . . . . . . . . . . . . . . . 52

19 Representação de um indivíduo no modelo DM. . . . . . . . . 53

20 Rede Bayesiana para um Trio . . . . . . . . . . . . . . 54

21 Comparação entre modelos - Família a estudar. . . . . . . . . 57

22 Teste da hipótese do demandado ser o pai biológico . . . . . . 58

23 Fluxo de funcionamento . . . . . . . . . . . . . . . 61 


\section{Agradecimentos}

Carlos A. Bragança Pereira (orientador)

Hugo A. Armelin (co-orientador)

Julio M. Stern

Fábio Cozman

Manoel Benevides

Martin Whittle

Marcelo Lauretto

Parentes e amigos

FAPESP

CAPES

\section{Introdução}

Esta tese contém resultados de alguns anos de trabalho cujo objetivo pode ser resumido em uma frase: "Construir um modelo matemático para cálculo da probabilidade de paternidade e implementá-lo em software". Analisando a frase com cuidado, cumprir este objetivo requer conhecer em certo nível de detalhe o processo biológico modelado, as técnicas de aquisição de dados, a matemática (estatística) envolvida e as técnicas de computação para implementar o modelo.

Este modelo se aplica a casos em que são conhecidos os genótipos (ou "perfil de DNA") dos indivíduos envolvidos ou de parentes destes e a relação de parentesco entre eles. O caso mais simples envolve dois indivíduos: o demandante ou reclamante, que reclama ser reconhecido como filho do segundo envolvido, o demandado. Casos simples como este ou envolvendo trios - demandante, demandado e o outro genitor do demandado - podem ser resolvidos com o auxílio de uma calculadora ou de uma planilha eletrônica. Em casos mais complexos, por exemplo quando o perfil do demandado não está disponível e seus irmãos são examinados, quando há outros vínculos discutíveis, por exemplo se um irmão do demandando não for legítimo ou há consangüineidade (figura 1), a quantidade e complexidade dos cálculos cresce, o que mostra a necessidade da automação do cálculo.

Um outro desafio consiste em comunicar a públicos de diferentes áreas de conhecimento o conteúdo deste trabalho de forma precisa e linear, sem tirar a 
possibilidade de saltar assuntos já conhecidos. Para isto optou-se por organizar esta tese em cinco capítulos. Os próximos dois contêm informação de base para o trabalho propriamente dito, apresentado nos outros três capítulos.

O capítulo 2 traz uma revisão sobre o processo biológico e as técnicas de aquisição de dados. Especial atenção deve ser prestada na definição de "marcador molecular", por suas semelhanças e diferenças com "gene", e de "mutação", que é diferente da usual. O capítulo 3 traz uma revisão sobre probabilidade, estatística e ferramentas utilizadas, como Redes Bayesianas e o Full Bayesian Significance Test (FBST). Neste capítulo também é apresentado o conceito de Equilíbrio de Hardy-Weinberg. O capítulo 4 traz o modelo proposto e comparação com o modelo de referência. O capítulo 5 traz o teste de equilíbrio. O capítulo 6 contém a explicação detalhada da implementação de todos os softwares com exemplos.

Os capíltulos 4, 5 e 6 contém os pontos inovadores deste trabalho de doutorado:

1. Uso de freqüências genotípica;

2. Uso do teste seqüencial de equilíbrio;

3. A implementação dos anteriores em software.

São softwares resultantes deste trabalho

1. Compilador de heredogramas para rede bayesiana baseada em freqüência alélica;

2. Compilador de heredogramas para rede bayesiana baseada em freqüência genotípica;

3. Implementação do teste de equilíbrio;

4. Documentador de heredogramas;

5. Documentador de redes bayesianas; 


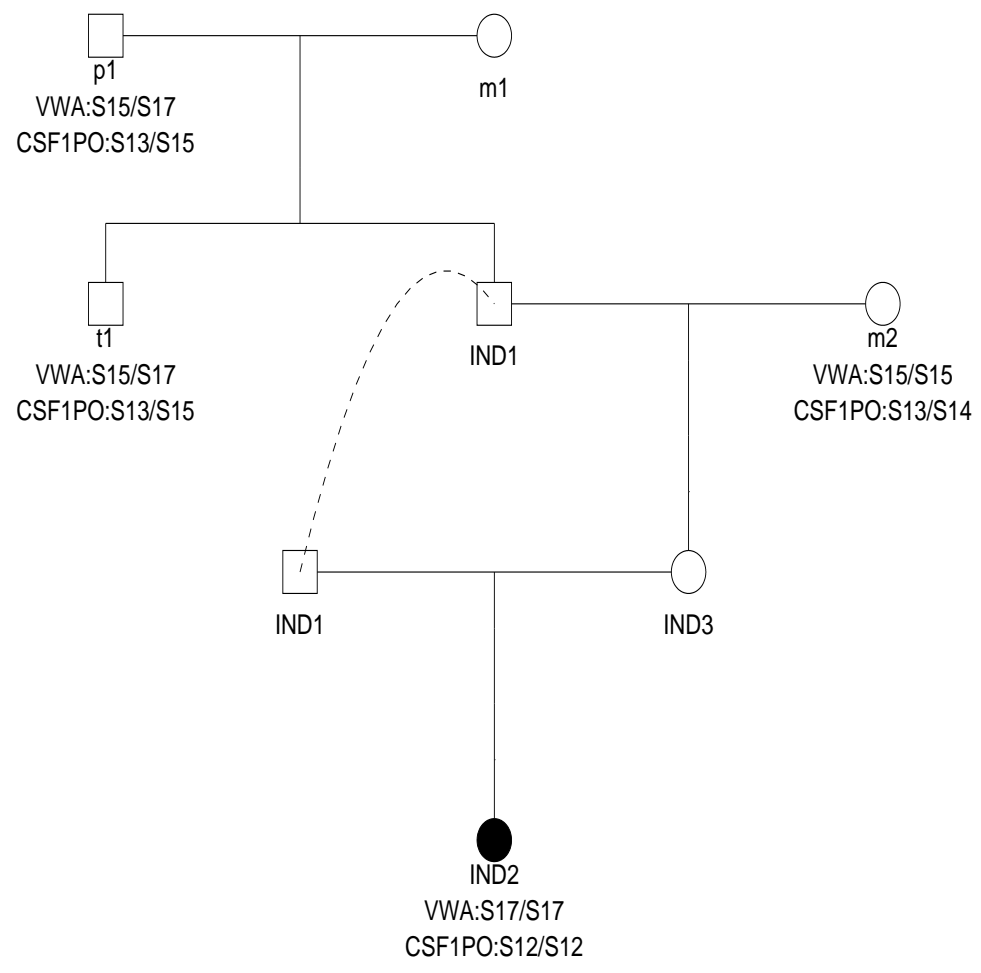

Figura 1: Exemplo de heredograma - Vínculo consangǘneo Neste heredograma os indivíduos de sexo masculino são representados por quadrados e os de sexo feminino por círculos. O reclamante é representado por um círculo cheio. Abaixo da forma seguem o nome do indivíduo e seu perfil de DNA, quando houver. Uniões (casamentos) são representados por linhas horizontais e vínculos de paternidade são representados por linhas verticais. Quando de uma união resulta mais de um filho, estes são ligados por uma linha em $\sqcap$. A linha tracejada mostra que o mesmo indivíduo é representado duas vezes. 


\section{Biologia - conceitos básicos e revisão histórica dirigida}

O objetivo neste capítulo é fazer uma revisão histórica das descobertas que relacionam o indivíduo ao seu "perfil de DNA", evidenciam como os perfis de DNA dos pais se relacionam com os dos filhos e embasam as técnicas para medição do perfil de DNA.

A revisão será iniciada a partir das Leis de Mendel, objetivando definir "perfil de DNA".

À frente do seu tempo, Gregor Mendel, em 1865 publicou o resultado de sua pesquisa sobre a herança de características em ervilhas [Mendel,1865 ]. O experimento consistia em anotar características físicas das plantas, como: cor e rugosidade da semente e cor da flor, e verificar o que ocorria com essas características em função do cruzamento controlado entre as plantas. Ele concluiu que a característica do indivíduo é determinada pela combinação de dois fatores e que os filhos herdam um dos fatores de seu pai e um dos de sua mãe.

Usando termos atuais e tomando como fenótipo a cor da semente, que pode ser verde ou amarela, um indivíduo pode ter um de três genótipos possíveis, dependendo da combinação de fatores (genes alelos) presentes no locus que determina a característica. Os dois alelos podem ser $V$, consequentemente o genótipo é $[V V]$ e o fenótipo amarelo. Se o locus contém um gene $V$ e um $v$, o genótipo é $[V v]$ e o fenótipo também é amarelo. Finalmente, se o locus contém dois genes $v$, o genótipo é $[v v]$ e o fenótipo é verde. Nota-se que, sabendo o fenótipo, há casos em que o genótipo não pode ser determinado univocamente.

Mendel verificou em seu experimento que, cruzando certa ervilha com fenótipo amarelo com outra de fenótipo verde, todos os filhos têm fenótipo amarelo, mas são diferentes dos pais, pois o cruzamento entre dois desses filhos gera $3 / 4$ dos netos de cor amarela e $1 / 4$ da cor verde. O modelo que ele propôs para explicar esse tipo de evidência experimental é de que um dos pais tem genótipo $[V V]$ e fenótipo amarelo, o outro tem genótipo $[v v]$ e fenótipo verde. $\mathrm{O}$ cruzamento resulta em todos os filhos com genótipo $[V v]$ e fenótipo amarelo, pois o gene para cor amarela - $V$ - é dominante e o para cor verde $-v$ - é recessivo. O genótipo $[V v]$ corresponde a todas as combinações dois a dois possíveis dos genes dos pais, conforme ilustrado na tabela 1. O cruzamento entre dois desses filhos de genótipo $[V v]$ resulta 
Tabela 1: Cruzamento entre homozigotos

\begin{tabular}{c|c|c|} 
& $\mathbf{V}$ & $\mathbf{v}$ \\
\hline $\mathrm{V}$ & $\mathbf{V V}$ & $\mathrm{V} \mathbf{v}$ \\
$\mathrm{V}$ & $\mathbf{V v}$ & $\mathbf{v} \mathbf{v}$
\end{tabular}

Tabela 2: Cruzamento entre heterozigotos

em $1 / 4$ dos netos com genótipo $[V V]$ e fenótipo amarelo, $1 / 2$ com genótipo $[V v]$ e fenótipo também amarelo e $1 / 4$ com genótipo $[v v]$ e fenótipo verde. Estas proporções ocorrem quando fazemos todas as combinações dois a dois possíveis dos genes dos filhos, como ilustrado na tabela 2.

No exemplo, apenas dois tipos de genes alelos, ou simplesmente genes, ou simplesmente alelos, são possíveis, $V$ ou $v$. Atualmente, sabe-se que há loci em que dezenas de alelos são possíveis, por exemplo, o locus FGA tem 47 alelos. O locus que determina o tipo sangüíneo (no sistema ABO) tem três alelos, $I^{A}, I^{B}$ e $i$ dos quais uma pessoa tem somente dois. Por exemplo, se o pai tiver genótipo $\left[I^{A} i\right]$ e a mãe tiver $\left[I^{B} i\right]$, o filho poderá ter um dos genótipos $\left\{\left[I^{A} I^{B}\right],\left[I^{A} i\right],\left[I^{B} i\right],[i i]\right\}$, os demais genótipos, $\left\{\left[I^{A} I^{A}\right],\left[I^{B} I^{B}\right]\right\}$ não podem ocorrer. Com três alelos há seis genótipos possíveis, mas dados os genótipos dos pais, os filhos podem ter um de no máximo quatro genótipos. Para quatro alelos, dos doze genótipos possíveis, dados os genótipos dos pais, no máximo quatro podem ocorrer no filho. Intuitivamente, quanto mais alelos houver, maior é o número de genótipos possíveis, mas dados os genótipos dos pais, no máximo quatro podem ocorrer no filho, logo, melhor pode se discriminar se esse trio (pai, mãe e filho) é verdadeiro ou não.

O processo de herança pode ser perturbado por mutações e seleção natural, o que resulta no desvio das freqüências genotípicas em relação às esperadas quando se usa o modelo de herança mendeliana. Tomando a cor das ervilhas como exemplo, entendendo mutação como um defeito genético que modifica funcionalmente o gene, independente do que ocorre no nível do DNA, se ocorrer uma mutação em que todos os genes $V$ se transformam (funcionalmente) em $v$, a geração seguinte de ervilhas apresentará apenas o genótipo (funcional) $[v v]$, independente do genótipo dos pais - o que é dife- 
rente de (quase) qualquer proporção esperada usando o modelo de herança mendeliana. Num novo exemplo, considerando seleção isoladamente, lembrando que o genótipo $[v v]$ implica em sementes verdes, se o ser humano tem preferência por ervilhas verdes a ponto de escolher e cultivar plantas que produzem sementes verdes, eliminando plantas que produzem sementes amarelas, mesmo que a transmissão dos genes ocorra como esperado, as proporções dos genótipos observados se alteram de geração em geração na direção da extinção do gene $V$.

A chance de que genes que determinam alguma característica sejam perturbados por esses eventos é grande se comparada com "elementos do genoma" que não determinam nenhuma característica. Mutações em genes podem gerar indivíduos inviáveis e processos seletivos como doenças, ou cruzamentos não aleatórios podem privilegiar certos genótipos. Desta forma, em identificação são utilizados "elementos do genoma" que até onde se sabe, não conferem ao indivíduo nenhuma característica. Rigorosamente, estes são chamados marcadores moleculares ideais. Existe um conjunto crescente de marcadores moleculares ideais utilizados em identificação e teste de paternidade, conforme documentado em Hammond [Hammond et al., 1994] e Lins [Lins et. al. 1998]. "Perfil de DNA" de um indivíduo é o nome dado ao conjunto dos genótipos do indivíduo para esses marcadores. Como se tratam de marcadores do material genético e são os únicos de interesse dentro do escopo deste trabalho, nas seções seguintes pode-se usar simplemente "marcador genético" para fazer referência aos marcadores moleculares ideais.

A medição do genótipo requer conhecimento da estrutura molecular dos marcadores e a confirmação do modelo proposto por Mendel requer conhecimento dos processos biológicos envolvidos, que foi acumulado durante mais de cem anos e serão revistos a seguir.

Utilizando certos corantes, o núcleo da célula fica muito visível. Os componentes do núcleo que ficam coloridos são os cromossomos, cujo nome deriva do grego, kroma significa cor, soma significa corpo. Karl Wilhelm von Nägeli em 1842 foi o primeiro a observá-los, embora esse nome tenha sido dado por H.W.G. Waldeyer-Hartz em 1888 [Waldeyer-Hartz,1888]. Em células constitutivas, os cromossomos ocorrem aos pares, chamados cromossomos homólogos. Por exemplo, o ser humano tem 23 pares de cromossomos.

Em 1882, Walther Flemming estudou um dos processos de divisão celular, batizando-o mitose [Flemming, 1882], representado no lado direito da figura 2. A mitose é dividida em cinco fases, intérfase, prófase, metáfase, anáfase e telófase, nomes dados por outros pesquisadores ao longo do tempo. $\mathrm{Na}$ 
intérfase, fase no intervalo entre divisões celulares, os cromossomos, visíveis como um emaranhado no núcleo da célula (mas representados como dois filamentos no desenho), são duplicados. Na prófase, ocorre a condensação dos cromossomos, que se tornam visíveis individualmente e os pares de homólogos se formam. Na metáfase os cromossomos se alinham no meio da célula e se ligam aos fusos acromáticos representados no terceiro desenho da mitose como fios ligados aos cromossomos. Na anáfase os cromossomos são puxados pelos fusos, separando as cromátides irmãs e inicia-se a divisão da célula (a membrana dá sinais de que a célula se dividirá em duas) como ilustrado no penúltimo desenho. Finalmente na telófase as duas membranas se formam, forma-se também a membrana nuclear.

Em 1879 Hermann Fol descreveu a entrada de um espermatozóide em uma ova [Fol, 1879], em 1883 Edouard van Beneden descreve a divisão celular com redução no número de cromossomos [Beneden, 1883]. Hipóteses sobre a utilidade desse tipo de divisão celular foram publicadas entre 1883 e 1885 por August Weismann [Weismann, 1883]. O nome meiose foi adotado em torno de 1890.

Meiose é a forma de divisão celular pela qual se formam os gametas óvulo e espermatozóide. Pode ser vista como duas mitoses em seqüência, mas sem a duplicação dos cromossomos entre a primeira e a segunda mitose, logo as quatro células resultantes têm apenas metade dos cromossomos das células que constituem um indivíduo. A meiose, como a mitose, inicia com a duplicação dos cromossomos na interfase como ilustrado na figura 2 lado direito, primeiro e segundo desenhos. Na prófase I os cromossomos homólogos se pareiam e se condensam, tornando-se visíveis. Na Metáfase I os cromossomos se alinham no centro da célula e se ligam aos fusos acromáticos, representados no quarto desenho pelos arcos ligados aos cromossomos. Nesta fase ocorre o crossing over ou seja, as cromátides irmãs trocam segmentos, como se embaralhassem. Na anáfase I as cromátides irmãs são puxadas e separadas, uma para cada extremidade da célula pelos fusos, em seguida ocorre uma divisão celular. Em seguida ambas as células entram em nova metáfase, os cromossomos se alinham no centro da célula e se ligam aos fusos acromáticos. Segue-se uma nova anáfase, em que os homólogos são separados e na telófase a divisão celular se completa, resultando em quatro células cada uma com um de cada um dos homólogos.

Em 1887 Theodor Boveri lançou a idéia de que os cromossomos são herdados[Boveri, 1887] e em 1902 mostrou, simultaneamente a Walter Sutton, como as idéias de Mendel se ajustam ao processo de divisão celular 


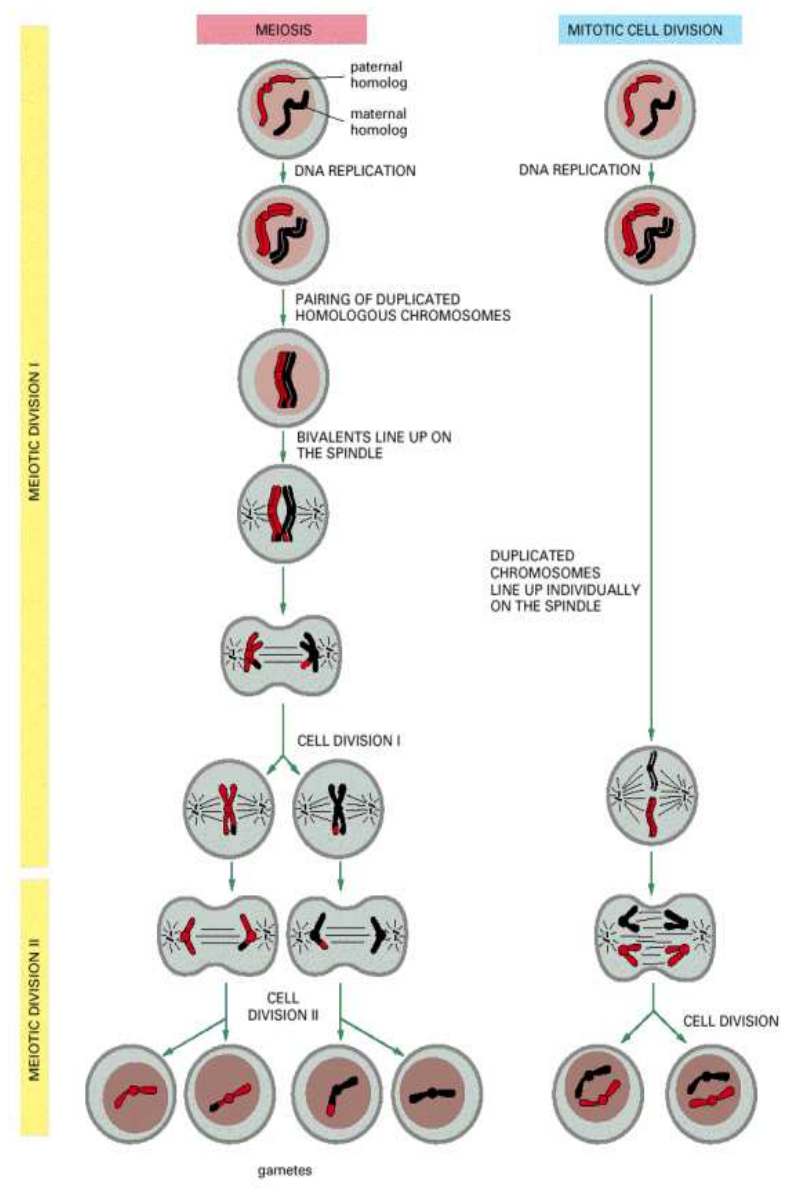

Figura 2: meiose e mitose

[Boveri,1902], [Sutton, 1902]. O termo "gene" para designar os fatores mendelianos foi criado por Walter Sutton.

A descoberta de Boveri e Sutton ocorreu após o biólogo dinamarquês Hugo de Vries ter redescoberto as leis de Mendel. de Vries defendia o Mutacionismo - teoria alternativa ao Darwinismo, onde novas espécies poderiam surgir por mudanças repentinas (mutações) e então selecionadas.

Thomas Hunt Morgan, na época pesquisador em zoologia experimental, adotou como modelo biológico para seus estudos em hereditariedade a mosca da fruta Drosophila melanogaster em 1907 e buscava um exemplar que exibisse claramente uma característica diferente, uma mutação. Em 1910 ele observou um macho de olhos brancos. Isto permitiu ao pesquisador explorar 
os mecanismos da herança Mendeliana. É de Morgan a afirmação de que em todas as espécies o óvulo e espermatozóide carregam um certo número de cromossomos e quando ocorre a fecundação os gametas se fundem gerando uma célula com cromossomos agrupados em pares. A partir deste ponto seguiram-se grandes descobertas feitas por Morgan e seus estudantes, como recombinação dos cromossomos, mapas genéticos e a conceituação de gene alelo, que compõe a teoria cromossômica da hereditariedade exposta em [Morgan,1915].

Em 1928 Frederick Griffith trabalhando com duas formas de pneumococos - uma bactéria que causa pneumonia - a forma S, que é capaz de reconhecer as células que ataca, portanto causa a doença, e a forma $\mathrm{R}$, incapaz desse reconhecimento devido a um defeito genético - um mutante - que não causa a doença, descobre o "princípio transformador". Em seu experimento, como controle, Griffith injetou camundongos ou com a forma S ou com a forma $\mathrm{R}$, e verificou que os que receberam a forma $\mathrm{S}$ (causa a doença) morriam, enquanto os que receberam a forma $R$ (não causa a doença) sobreviviam, como ilustrado na figura 3 desenhos 1 e 2 . Matando as células $\mathrm{S}$ por calor e injetando essa solução em um camundongo, este sobrevivia, entretanto, se o camundongo recebesse a solução misturada com a bactéria viva na forma $\mathrm{R}$ (não causa a doença), inesperadamente, esse morria e era detectável a forma S do pneumococo (figura 3). A conclusão a que Griffith chegou é de que existe um "princípio transfomador" nessas bactérias, transmitido mesmo após sua morte.

Em 1944, Avery, McLeod e McCarthy mostraram que o princípio transformador é o DNA [Avery,1944]. Eles procuraram o que causava a transformação purificando algum componente das células $\mathrm{S}$ mortas e injetando essa mistura em camundongos, repetindo o experimento de Griffith usando cada componente separadamente. Na época, eram poucas as técnicas de purificação disponíveis, mesmo assim, após dez anos de pesquisa, eles descobriram que tal princípio não era afetado por enzimas que degradam proteínas (proteases), como tripsina e chimotripsina nem por enzimas que degradam RNA (RNAses ou ribonucleases), mas deixava de existir se tratado por enzimas que degradam DNA (DNAses ou deoxirribonucleases), concluindo que o princípio transfomador é o DNA (figura 4).

Em 1941 Beadle - que foi aluno de Morgan e Sturtevant - e Tatum formularam a hipótese de que existe uma relação de um gene para uma enzima [Beadle,Tatum,1941]. O experimento consistiu em causar mutações em um fungo cultivado em "meio completo" e transferir esse fungo para meios mais 
(B)
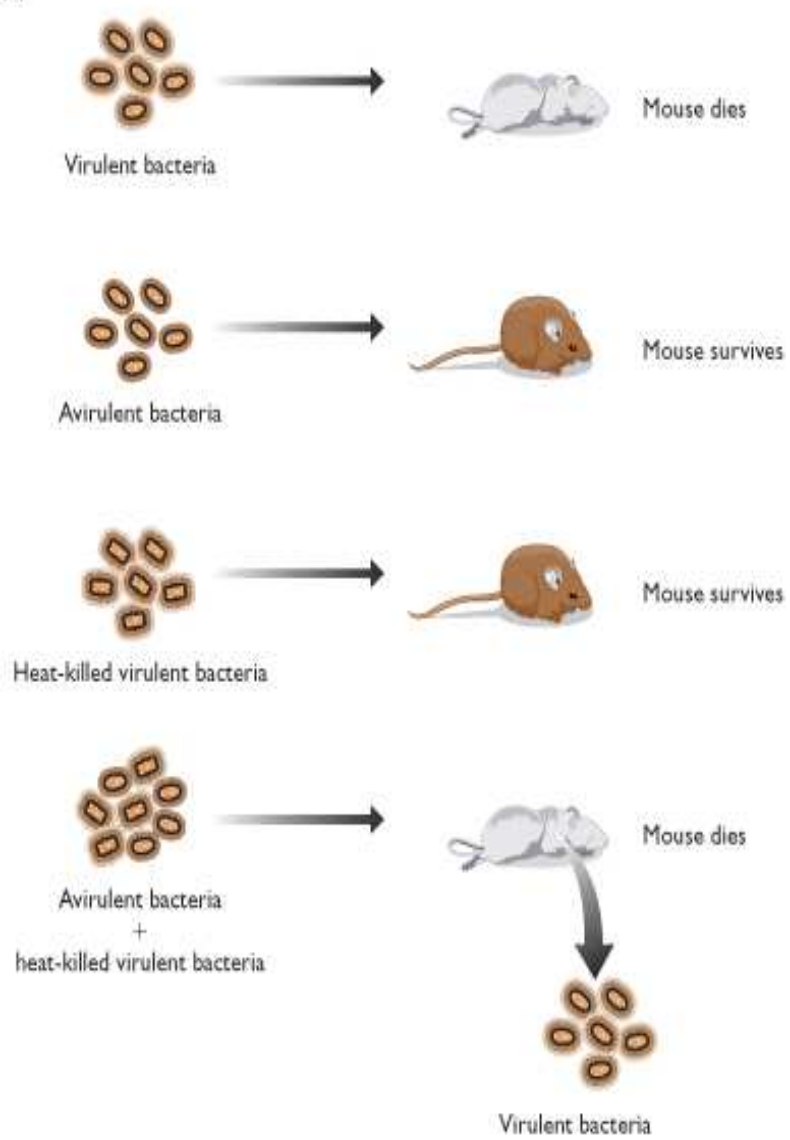

Figura 3: Experimento de Griffith - Princípio Transformador

pobres, identificando os componentes do meio essenciais para a sobrevivência de cada mutante. No passo seguinte esses mutantes eram cruzados com fungos "normais" e a freqüência do gene mutado na geração seguinte indica quantos genes sofreram mutação.

Em 1953, Watson e Crick publicam a estrutura em dupla hélice do DNA e o pareamento entre as bases [Watson,Crick,1953]. A molécula de DNA é uma longa sucessão das quatro bases nitrogenadas possíveis: Adenina, Timina, Citosina ou Guanina. Esses são os nomes das cadeias laterais, representadas, respectivamente, em azul, amarelo, vermelho e verde na figura 5-B. Pelas características moleculares dessas bases e conformação da molécula de DNA como um todo, as bases tendem a se parear, A com T, C com G. Embora esse 


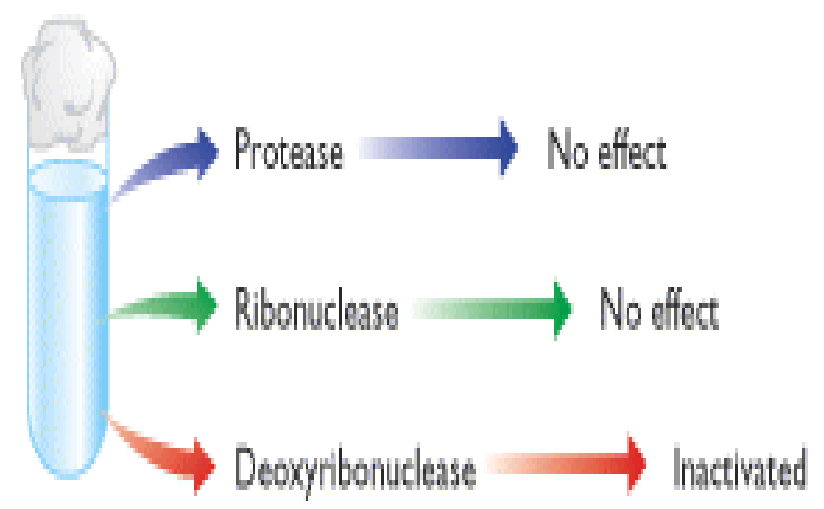

Figura 4: Experimento Avery, McLeod, McCarty - DNA é o princípio transformador

não seja o único pareamento possível, é muito mais provável que qualquer outro, sendo que na célula há mecanismos que corrigem pareamentos diferentes desses. Mesmo fora das células, esse pareamento é muito forte e muito específico, ou seja, pares diferentes são muito pouco prováveis. Assim, duas moléculas (fitas) de DNA, se forem complementares, ou seja a seqüência de uma pareia com a seqüência de outra, se associam formando uma fita dupla. Essa associação é desfeita com o calor, resultando em fitas simples - processo chamado denaturação - e se refaz em condições favoráveis de resfriamento e agitação. A este processo de associação controlada é dado o nome de hibridização. Por características fisico-químicas de seus componentes, essa fita dupla é torcida, formando a dupla-hélice, que pode ser vista na figura 5-A em um gráfico de preenchimento onde os átomos de oxigênio estão em vermelho, os de hidrogênio em branco, carbono em azul e fósforo em laranja. No gráfico, a "coluna" de cada uma das hélices é vista se forem seguidos os átomos de fósforo (em laranja) ligado aos três átomos de oxigênio (em vermelho). É importante ressaltar que cada base tem uma carga negativa associada ao átomo de oxigênio ligado ao átomo de fósforo, esta característica é importante para a identificação do genótipo.

Em 1956 Arthur Kornberg isola a DNA polimerase I em E.coli e mostra que, a partir de uma fita simples de DNA - que ela usa como molde - esta enzima é capaz de sintetizar a fita complementar [Kornberg,1958]. Para que a duplicação ocorra, são necessárias também as bases $\{A, T, C, G\}$ que serão usadas para construir a fita complementar e uma seqüência curta, de dez a vinte bases, que serve como iniciador primer para o processo. Como a 


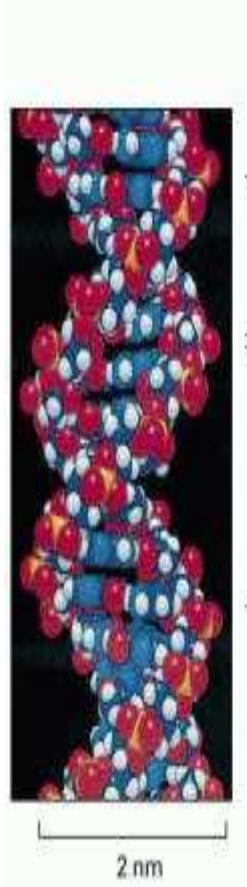

(A)

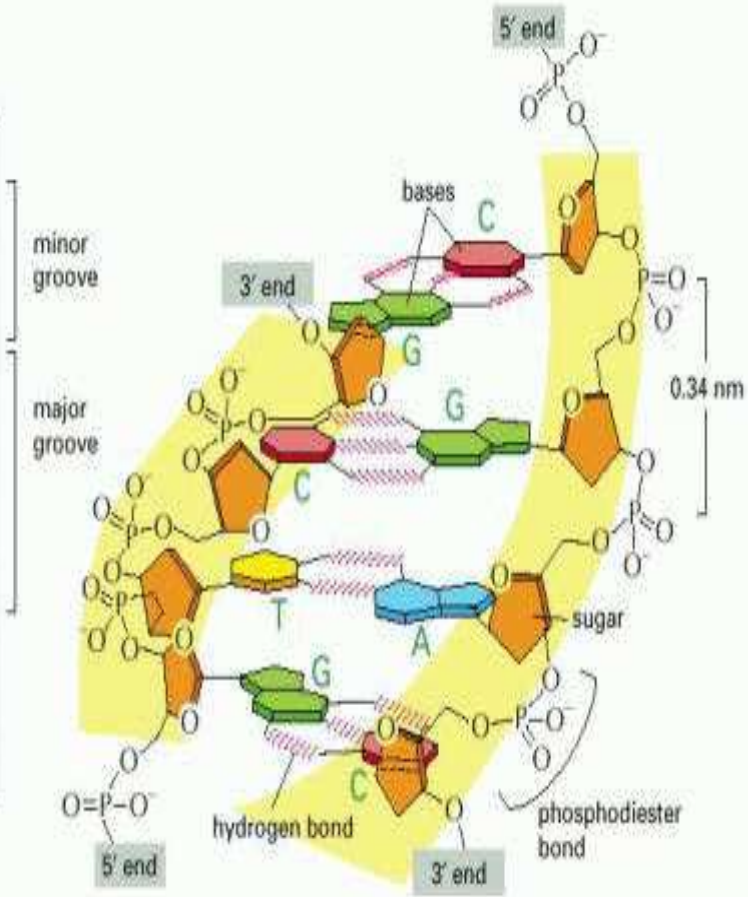

(B)

Figura 5: Estrutura do DNA

enzima somente é capaz de acrescentar bases à extremidade de uma fita, utilizando a outra como molde, esta extremidade precisa estar presente, esta é a função do iniciador. Primeiramente, o iniciador tem que se hibridizar à fita molde, formando fita dupla em um trecho curto. A enzima se associa ao DNA na extremidade desse trecho e passa a acrescentar bases à extremidade do iniciador seguindo o pareamento Watson-Crick, como ilustrado na figura 6. Considerando que esta seja a única maneira do DNA ser copiado, algo que começa a ser questionado ( como se pode ver em [Lolle, 2005]), pode-se afirmar que a seqüência de bases do DNA, e conseqüentemente os genes, são passados quase sem alteração dos pais para os filhos.

Existem alguns fatores que podem perturbar esse processo de cópia, por exemplo a exposição à radiação ou certos agentes químicos pode destruir parte do DNA ou alterar a seqüência de bases. Também a DNA polimerase pode incorporar a base errada, o que ocorre com taxa de aproximadamente $10^{-7}$. Dependendo da extensão dos danos eles podem ser corrigidos, ou 
a célula cujo DNA sofreu esses danos pode entrar em um ciclo de morte programada, mas às vezes a célula sobrevive. Neste caso diz-se que ela sofreu uma mutação, mas que continua viável. Este é um fato que precisa ser levado em consideração quando o modelo do processo for construído. Quando ocorre defeito em apenas uma base do DNA, diz-se que ocorreu uma mutação pontual.

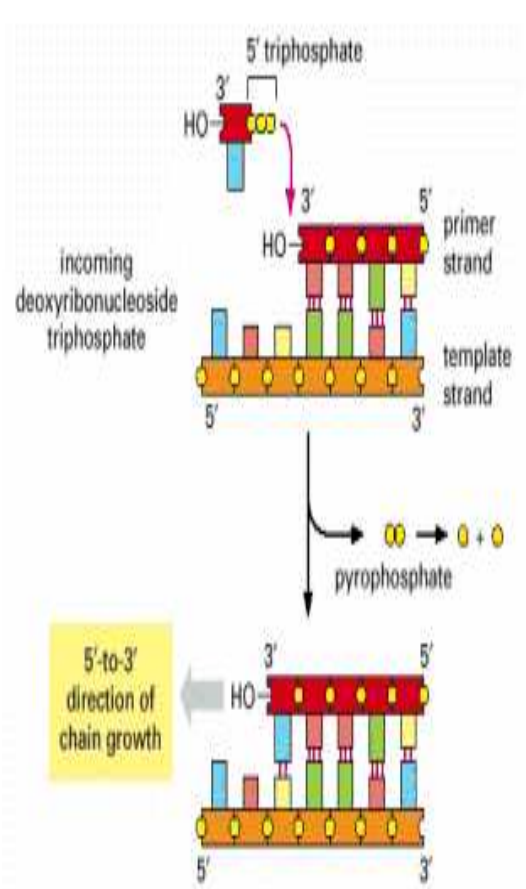

(A)

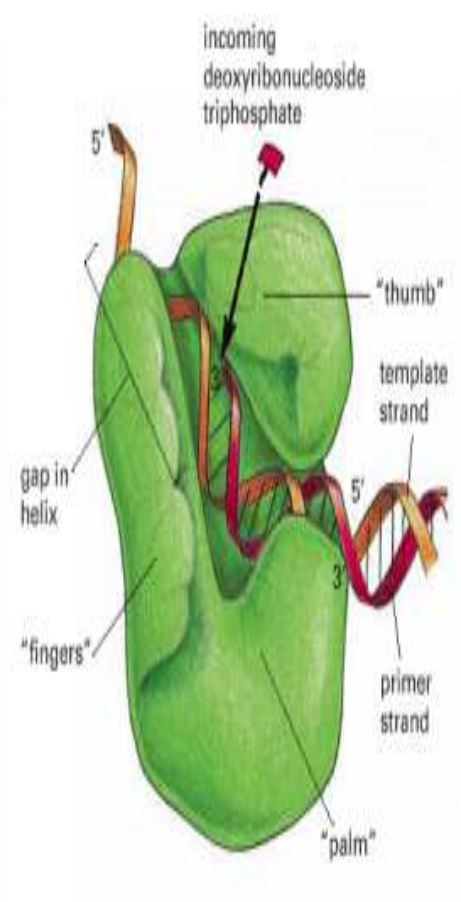

$|B|$

Figura 6: DNA Polimerase

A DNA polimerase é fundamental para a técnica de cópia de DNA chamada reação em cadeia de polimerase ou PCR, técnica criada na década de 60 e automatizada por Kerry Mullis em 1985 [Mullis, 1985], para a partir de pequenas amostras de DNA, mesmo com um certo nível de degradação, obter uma quantidade razoável de cópias dos marcadores genéticos presentes na amostra. Com essa finalidade, utiliza-se a Taq DNA polimerase originária de uma bactéria aquática (Thermophilus aquaticus) que vive próximo a fontes termais e vulcões submarinos. As proteínas dessa bactéria se mantêm funcionais a temperaturas a temperaturas em que o DNA se denatura, o 
que permite fazer a cópia do DNA automaticamente em um termo-ciclador. Este equipamento gera ciclos de aquecimento e resfriamento em uma mistura que contém a amostra, dNTPs - trifosfatos das quatro bases nitrogenadas (A,T,C,G), a enzima Taq polimerase e os iniciadores - seqüências curtas de DNA complementares às regiões que delimitam os marcadores.

A reação se inicia, como indicado na figura 7 , a $95^{\circ} \mathrm{C}$, temperatura em que o DNA da amostra se denatura e são acrescentados dois iniciadores (primers), dNTPs (dATP, dTTP, dCTP e dGTP) e a Taq Polimerase. Abaixando a temperatura, os iniciadores se hibridizam ao DNA da amostra (figura 7 ciclo 1 passo 2). A $60^{\circ} \mathrm{C}$ a Taq polimerase sintetiza as cadeias complementares a partir dos iniciadores, dobrando a quantidade de fitas de DNA (figura 7 ciclo 1 passo 3). As fitas não são completamente duplicadas, é suficiente que apenas o marcador seja duplicado, o que se consegue deixando a polimerase agir por tempo suficiente, interrompendo-se o processo pelo aquecimento da amostra até $95^{\circ} \mathrm{C}$, quando inicia o segundo ciclo. A esta temperatura, o DNA se denatura, e quando é novamente resfriado, ocorre a hibridização dos iniciadores (figura 7 ciclo 2 passo 1 ), a $60^{\circ} \mathrm{C}$ a polimerase novamente sintetiza as cadeias complementares (figura 7 ciclo 2 passo 2 ), mais uma vez dobrando a quantidade de fitas de DNA. A cada ciclo térmico, a quantidade de segmentos que contém o marcador (quase) dobra. Esses segmentos têm o mesmo comprimento e peso.

No início do processo, antes do primeiro ciclo, há somente $n$ fitas de DNA vindas da amostra, ao fim do primeiro ciclo, se a reação for ideal, haverá uma mistura de $n$ fitas e $n$ semi-fitas - cópias das fitas, de peso variável em apenas uma direção. Ao fim do terceiro ciclo haverá, na mistura, $n$ fitas, $2 * n$ semi-fitas e $n$ segmentos - cópias das semi-fitas e com comprimento bem definido. Ao fim do quarto ciclo haverá $n$ fitas, $3 * n$ semi-fitas e $4 * n$ segmentos, Ao fim do quinto ciclo haverá $n$ fitas, $4 * n$ semi-fitas e $(8+3) * n$ segmentos. A quantidade de fitas na mistura não se altera, a quantidade de semi-fitas crescem linearmente e a de segmentos, exponencialmente. Ao final de uma quantidade razoável de ciclos a quantidade de segmentos será muito maior que as outras. Após o PCR, o DNA é separado em função da peso utilizando eletroforese.

Na eletroforese, a amostra é depositada sobre uma coluna de gel, como ilustrado na figura 8-A. Esse gel tem poros que deixam passar, com resistência (ou atrito, se utilizarmos um modelo físico) proporcional ao tamanho e conseqüentemente ao peso das moléculas da amostra. $\mathrm{O}$ gel e a amostra são submetidos a um campo elétrico, como a amostra é feita de DNA que, como 


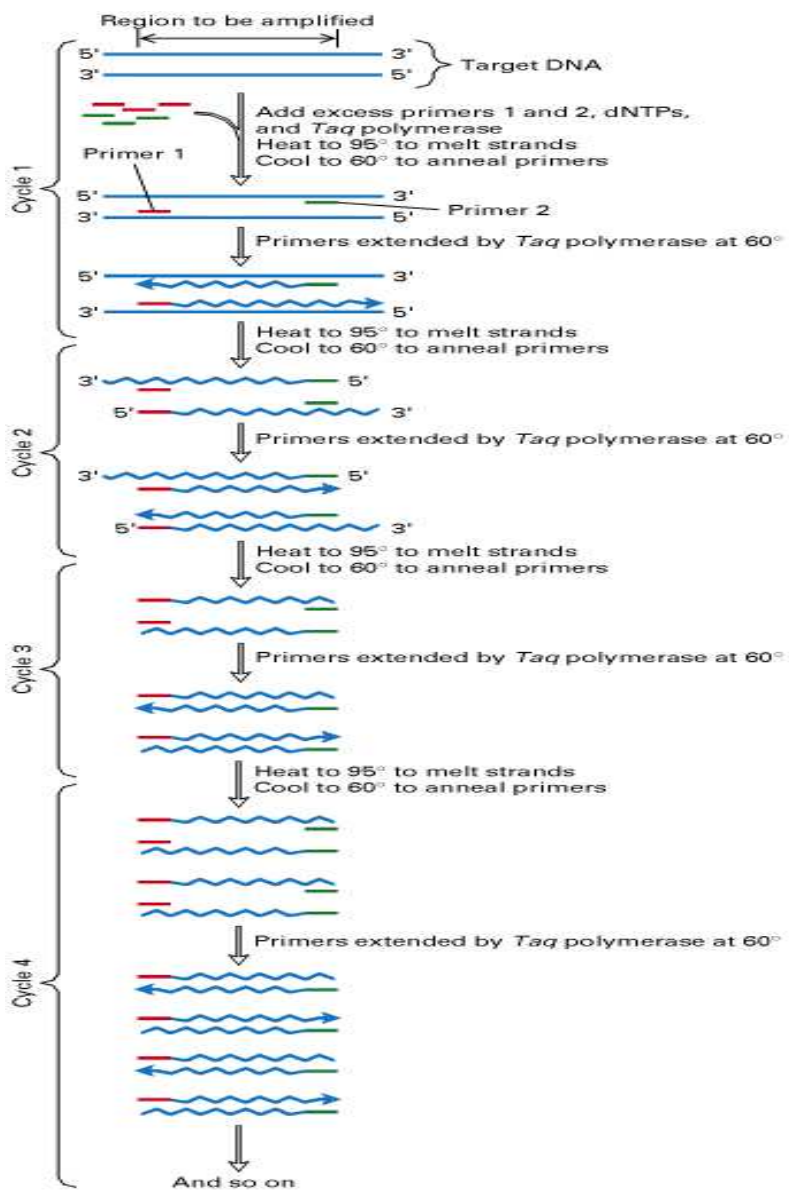

Figura 7: Reação em Cadeia de Polimerase

já dito anteriormente tem carga elétrica negativa, vai se deslocar em direção ao pólo positivo que está conectado à cuba inferior, a cuba superior está conectada ao pólo negativo, o que gera o campo no gel - a placa com poçcos entre as cubas. Na figura 8-B apresentam-se o estado inicial do gel, com a mistura depositada na parte superior e o estado final com as moléculas menores e mais leves, que migraram mais longe, abaixo e as maiores, que migraram menos, acima.

Várias amostras podem ser separadas ao mesmo tempo no mesmo gel em poços diferentes, em especial, um dos poços pode conter um padrão com todos os alelos possíveis para o marcador, então por comparação entre a amostra e o padrão se determina o genótipo do indivíduo que forneceu a amostra. $\mathrm{Na}$ 


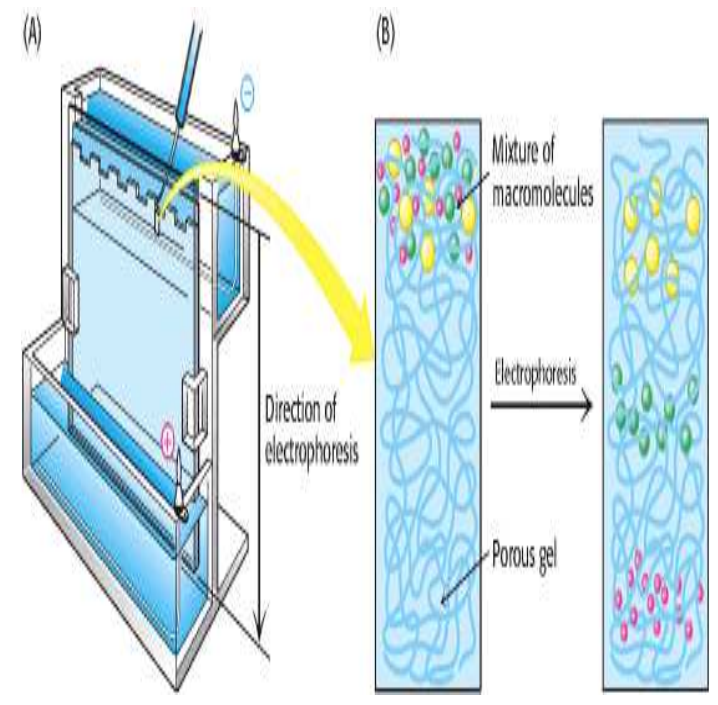

Figura 8: Eletroforese

Nota: cubas verticais como esta geralmente são usadas na eletroforese de proteínas e não em DNA, mas os conceitos envolvidos são os mesmos.

figura 9 o primeiro e o último poço (coluna) contém o padrão, ou seja, todos os alelos possíveis. O segundo e o terceiro contém amostras provenientes do pai e do filho. Ambos são heterozigotos pois há duas bandas, uma para cada alelo. Contando as bandas de baixo para cima, pai e filho têm em comum o alelo na terceira banda, o alelo da quinta banda do filho deve ter vindo de sua mãe.

Neste processo de medição podem ocorrer erros, por exemplo, se o PCR falhar para um dos alelos da amostra de um heterozigoto, na eletroforese aparecerá apenas uma banda e o indivíduo será considerado homozigoto. Também um alelo pode ser trocado pelo seu vizinho, pela proximidade das bandas ou por alguma não homogeneidade do gel.

Há laboratórios que adotam um outro processo de medição. Optaram por seqüenciar os marcadores, ou seja, o dado medido é a seqüência de bases do marcador encontrado na amostra. Com este procedimento é possível ver se o PCR falhou para algum dos alelos, erros de identificação de alelos também são menos prováveis e até mutações pontuais podem ser detectadas.

O seqüenciamento, da forma como o processo de medição de genótipo é abordados aqui, pode ser visto como uma variação do primeiro processo pois também envolve uma etapa de multiplicação por PCR e uma etapa de 


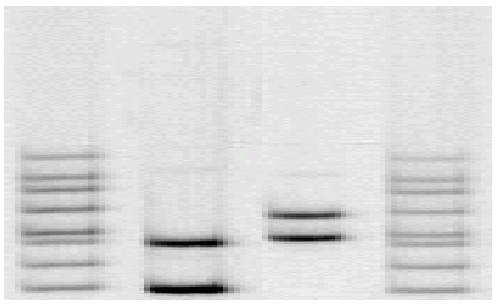

Figura 9: Gel para um marcador

separação feita por cromatografia em lugar da eletroforese. No PCR para seqüenciamento, são acrescentados à mistura os dideoxirribonucleosídeos (ddNTPs) para as quatro bases (ddATP, ddTTP, ddCTP e ddGTP) marcadas cada uma com um diferente fluoróforo - molécula que quando irradiada com laser emitem luz em um certo comprimento de onda. Quando um ddNTP é incorporado à cadeia de DNA, o crescimento da cadeia é interrompido e nenhuma outra base é acrescentada. A última base incorporada também é identificável pelo comprimento de onda da luz que emite. Como as massas das cadeias são crescentes em função da quantidade de bases, separando a mistura resultante do PCR com resolução de uma base, obtém-se a seqüência (figura 10).

Esses resultados permitiram a construção de produtos comerciais para identificação dos genes de indivíduos, como descrito por Hammond [Hammond et al., 1994] e Lins [Lins et. al. 1998]. 


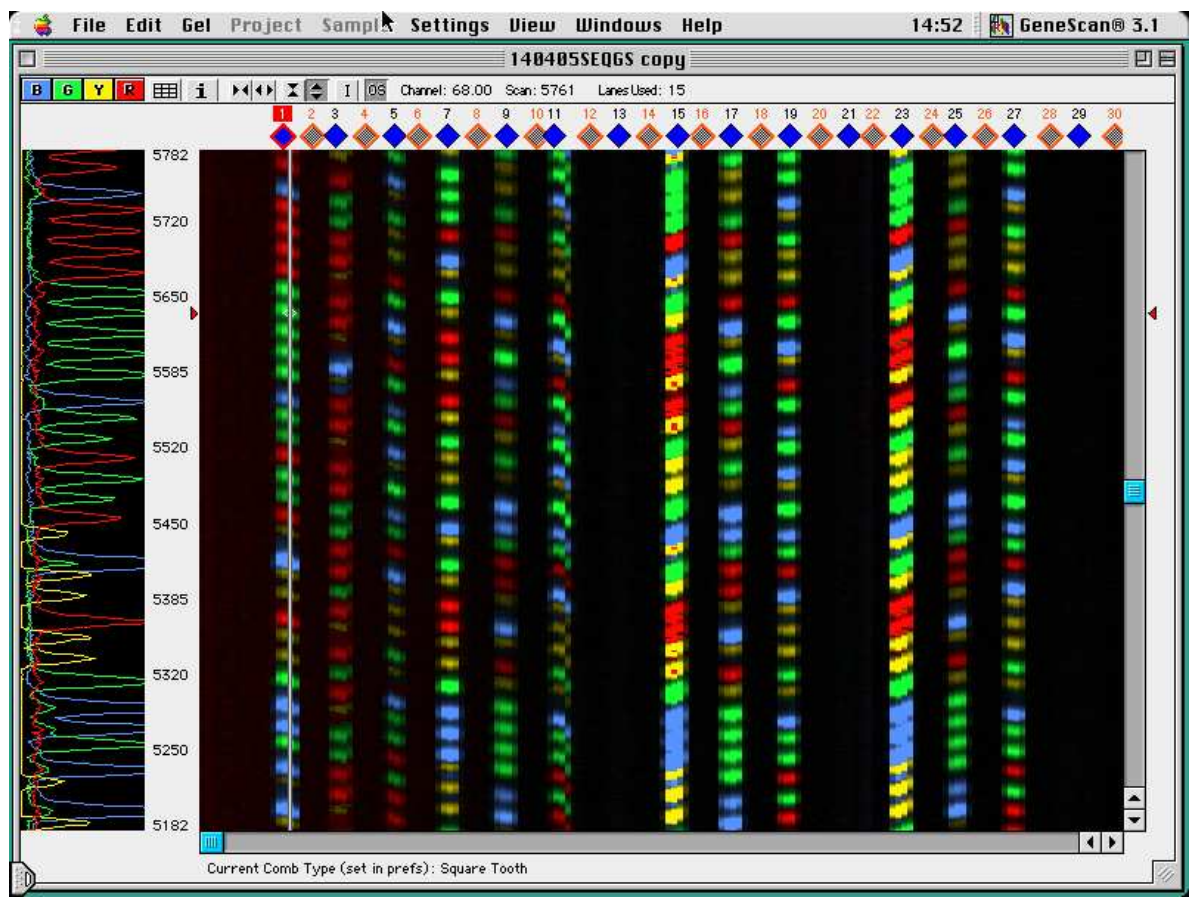

Figura 10: cromatograma de seqüenciamento

Nesta figura, cada base é representada por uma cor: $A=A z u l, G=V e r d e$, $\mathrm{C}=$ Amarelo e $\mathrm{T}=$ Vermelho, como indicado no canto superior esquerdo da janela. 27 amostras são seqüenciadas e o sinal da seqüência 1 é mostrada no cromatograma da lateral esquerda. A seqüência é lida de baixo para cima, a cor com pico mais alto (intenso) indica a base mais provável. Na região que inicia na seta vermelha, a seqüência mais provável é GGTTTTAA. 


\section{Referências}

[Mendel,1865 ]

[Hammond et al., 1994]

[Lins et. al. 1998]

[Fol, 1879]

[Flemming, 1882]

[Beneden, 1883]

[Waldeyer-Hartz,1888]
MENDEL, GREGOR - Versuche über PflanzenHybriden - Vorgelegt in den Sitzungen vom 8. Februar und 8. März 1865 (tradução para o inglês em www.mendelweb.org

HAMMOND, HOLLY A., LI JIN, Y. ZHONG, C. THOMAS CASKEY, RANAJIT CHAKARBORTY Evaluation of 13 Short Tandem Repeat Loci for Use in Personal Identification Applications - American Journal of Human Genetics v. 55 pp 175-189

LINS, ANN M., KATHERINE A. MICKA, CYNTHIA J. SPRECHER, JENNIFER A. TAYLOR, JEFFREY W. BACHER, DAWN R. RABBACH, ROBERT A. BEVER, STEVEN D. CREACY, JAMES W. SCHUMM Development and Population Study of an Eight-Locus Short Tandem Repeat (STR) Multiplex System - Journal of Forensic Sciences v. 43 pp 1168-1180

FOL, H. Recherches sur la Fécondation et le commencement de L'Hénogénie chez divers animaux. - Mémoires de la Soc. de Physique et d'Histoire Naturelle de Genéve 26, 1879.

FLEMMING, WALTHER - Zell-substanz, Kern und Zelltheilung - (Cell-Substance, Nucleus, and Cell-Division), 1882 (book)

BENEDEN, EDOUARD VAN - Recherches sur la maturation de l'oeuf et la fècondation - Arch. Biol. 4 (1883): 610-20.

WALDEYER-HARTZ, H.W.G. Über Karyokinese und ihre Beziehungen zu den Befruchtungsvorgängen - Archiv für mikroskopische Anatomie und Entwicklungsmechanik, 1888, 32: 1-122. 
[Weismann, 1883]

[Boveri, 1887]

[Boveri,1902]

[Sutton, 1902]

[Morgan,1915]

[Avery,1944]

[Beadle,Tatum,1941]

[Watson,Crick,1953]
WEISMANN, AUGUST, Aufsätze über Verebung und verwandte biologische Fragen. (translated by Edward B. Poulton), Essays Upon Heredity and Kindred Biological Problems., Authorized Translation, (Clarendon Press, Oxford, 1889, volume 2 was translated in 1892). This is a 2 volume set.

BOVERI, TH. Über die Befruchtung des Eies von Ascaris megalocephala. - Sitz. Ber. d. Ges. f. Morph. u. Phys. Munchen, Bd. 3. 1887.

BOVERI, TH. Über mehrpolige Mitosen als Mittel zur Analyse des Zellkerns. - Verhandlungen der physicalisch-medizinischen Gesselschaft zu Würzburg. Neu Folge 35: 67-90.

SUTTON, W. S. - On the morphology of the chromosome group in Brachystola magna. Biol Bull. 4:24-39, 1902.

MORGAN T. H., STURTEVANT A.H., H.J. MUELLER H.J and C.B. BRIDGES C.B - The Mechanism of Mendelian Heredity. New York, Henry Holt, 1915

AVERY, OSWALD T., COLIN M. MACLEOD, and MACLYN MCCARTY - Studies on the Chemical Nature of the Substance Inducing Transformation of Pneumococcal Types. - Journal of Experimental Medicine 79, 2 (1 February 1944): 137-158.

BEADLE, G.W.,TATUM,E.L - Genetic Control of Biochemical Reactions in Neurospora 1941, Proc. Nat. Ac. Sci. v.27

WATSON, J.D., CRICK, F.H.C. - Molecular structure of nucleic acids. A structure for deoxyribose nucleic acid. - Nature 171, 737-738 (1953). 
[Kornberg, 1958]

[Lolle, 2005]

[Mullis, 1985]
LEHMAN IR, BESSMAN MJ, SIMMS ES, KORNBERG A. - Enzymatic synthesis of deoxyribonucleic acid. I. Preparation of substrates and partial purification of an enzyme from Escherichia coli. J Biol Chem. 1958 Jul;233(1):1632013170.

LOLLE, SUSAN J., JENNIFER L. VICTOR, JESSICA M. YOUNG, ROBERT E. PRUITT - Genome-wide non-mendelian inheritance of extra-genomic information in Arabidopsis, Nature 2005)

MULLIS K. B; FALOONA F. A; SCHARF S; SAIKI R. K; HORN G; ERLICH H. A. - Specific enzymatic amplification of DNA in vitro: the polymerase chain reaction. - ColdSpringHarbor Symposia on Quantitative Biology, 1986 


\section{Probabilidade e Estatística - conceitos e ferramentas utilizados neste trabalho}

Neste capítulo pretende-se fazer uma revisão sobre probabilidade e estatística a fim de explicar os modelos e testes estatísticos utilizados no restante da tese.

Considera-se que o tratamento analítico da probabilidade foi inicialmente proposto por Blaise Pascal e Pierre Fermat em meados do século XVII a fim de estudar certos jogos de dados. Alguns desses resultados já tinham sido dados por Girolamo Cardano(1501-1576) e Galileo Galilei(1564-1642), outros foram grandes descobertas [DeGroot,2002 ].

Numa leitura rápida de [Stigler, 1994] nota-se que a evolução cronológica da disciplina é diferente da ordem em que os tópicos da disciplina são ministrados. Por exemplo, os axiomas do cálculo de probabilidade foram formalizados com sucesso em 1930 por Kolmogorov [Kolmogorov,1933] e em 1961 por Cox [Cox,1961] embora antes de tal formalização, em 1763, Bayes tivesse tido seu teorema [Bayes, 1763] publicado (postumamente). Essa diferença na ordem dos tópicos parece ser resultado colateral da necessidade de explicar os tópicos em uma única linguagem, o que dificulta a apresentação dos tópicos em ordem cronológica.

\subsection{Conceitos}

Utilizando a formalização de Kolmogorov, o conjunto de todos os eventos possíveis em um experimento é chamado espaço amostral - $S=\left\{A_{1}, A_{2}, A_{3} \ldots\right\}$ - por exemplo, $S$ pode ser o conjunto de faces que podem ocorrer em um lançamento de dados. Em outro experimento pode-se considerar o evento $A_{1}=\{2,4,6\}$ como o conjunto de faces pares e os demais eventos correspondem à ocorrência de alguma outra face - $A_{2}=\{1\} \quad A_{3}=\{3\} \quad A_{4}=\{5\}$. Em todo caso, probabilidade é uma atribuição de números a cada evento que satisfaz a três condições (axiomas):

1. Probabilidade é um número não negativo, ou $\operatorname{Pr}\left(A_{i}\right) \geq 0 \forall A_{i} \in S$. Lê-se "a probabilidade da variável aleatória $a$ assumir o valor $A_{i}$ é maior ou igual a zero. Neste caso é importante notar que o valor de $a$ é indeterminado e $A_{i}$ é um certo evento. Num lançamento de moeda, os eventos possíveis são $A_{1}=$ cara, $A_{2}=$ coroa, a probabilidade de 
ocorrer algum dos eventos é $\operatorname{Pr}\left(A_{i}\right)$ e $S=\left\{A_{1}, A_{2}\right\}$ é o conjunto de todos os eventos possíveis.

2. $\operatorname{Pr}(S)=1$. A probabilidade de ocorrência de algum evento é um. Como $S$ é a união de todos os eventos possíveis, certamente um deles ocorre.

3. A probabilidade da união de eventos disjuntos é a soma das probabilidades dos eventos, ou $\operatorname{Pr}\left(\bigcup_{i} A_{i}\right)=\sum_{i}\left(\operatorname{Pr}\left(A_{i}\right)\right)$

Da definição de probabilidade seguem várias propriedades importantes:

1. Dado um conjunto de eventos, $B=\bigcup A_{i}$ com probabilidade $\operatorname{Pr}(B)$, a probabilidade do conjunto complementar, ou seja, o conjunto de todos os elementos que estão em $S$ mas não estão em $B, B^{c}$ vale $\operatorname{Pr}\left(B^{c}\right)=$ $1-\operatorname{Pr}(B)$.

2. Se $B \subset C$ então $\operatorname{Pr}(B) \leq \operatorname{Pr}(C)$. Em especial, se $C=S, C$ é o conjunto de todos os eventos possíveis, $\operatorname{Pr}(C)=1$, logo,

3. Para qualquer conjunto de eventos $B, 0 \leq \operatorname{Pr}(B) \leq 1$

4. Para dois conjuntos de eventos $B$ e $C$ quaisquer $\operatorname{Pr}(B \cup C)=\operatorname{Pr}(B)+$ $\operatorname{Pr}(C)-\operatorname{Pr}(B \cap C)$

Acrescenta-se a estes, o conceito de probabilidade condicional como a probabilidade de um evento $B$ ocorrer dado que um evento $C$ ocorreu, ou

$$
\operatorname{Pr}(B \mid C)=\frac{\operatorname{Pr}(B, C)}{\operatorname{Pr}(C)}
$$

Esta fórmula pode ser interpretada como uma mudança de escala, ou normalização devido à mudança do espaço de eventos de $U$ para o sub-espaço de $U$ em que $C$ ocorreu. Nesta nova situação, $\operatorname{Pr}(C)=1$, consequentemente as probabilidades de todos os eventos possíveis têm que ser escaladas para refletir a ocorrência de $C$, neste caso, divididas por $\operatorname{Pr}(C)$ na situação inicial. Além disso, eventos que envolvem a não ocorrência de $C$ passam a ter probabilidade zero, em especial, $\operatorname{Pr}(B \backslash C)=0$

Baseado nas probabilidades condicionais chega-se à fórmula de Bayes, contribuição de Thomas Bayes para a probabilidade e estatística, que foi publicada em 1754, após sua morte, como solução para o problema de inversão 
da probabilidade. Tomando como exemplo um dado "honesto" de seis faces, o problema "direto" era prever o resultado de lançamentos do mesmo e o problema "inverso" seria obter informação - inferir - a respeito do dado considerando o resultado dos lançamentos - assunto constante em ciências experimentais. Voltando à notação matemática, o cálculo de $\operatorname{Pr}(A \mid B)$ baseado em $\operatorname{Pr}(B \mid A)$.

sabe-se que as probabilidades condicionais são dadas por:

$$
\begin{gathered}
\operatorname{Pr}(A \mid B)=\frac{\operatorname{Pr}(A, B)}{\operatorname{Pr}(B)} \\
\operatorname{Pr}(B \mid A)=\frac{\operatorname{Pr}(A, B)}{\operatorname{Pr}(A)} \Leftrightarrow \operatorname{Pr}(A, B)=\operatorname{Pr}(B \mid A) * \operatorname{Pr}(A)
\end{gathered}
$$

$\log 0$

$$
\operatorname{Pr}(A \mid B)=\frac{\operatorname{Pr}(B \mid A)}{\operatorname{Pr}(B)} * \operatorname{Pr}(A)
$$

onde $\operatorname{Pr}(B)$ é obtido através do teorema da probabilidade total como $\operatorname{Pr}(B)=$ $\sum_{\forall A} P(B \mid A) * P(A)$

Colocando em prática a fórmula de Bayes sobre um problema que diz respeito a esta tese, considere o cálculo da probabilidade do genótipo do pai em um trio (pai, mãe, filho) para um locus com dois alelos possíveis $\left\{A_{1}, A_{2}\right\}$. A probabilidade apresentada na tabela, $\operatorname{Pr}$ (genótipo do filho|genótipo do pai,... genótipo da mãe) se refere à probabilidade de ocorrência do genótipo do filho, dado o do pai e da mãe considerando o processo de herança mendeliana o problema "direto". Esses genótipos (eventos) são apresentados na primeira coluna da tabela na ordem (pai, mãe, filho), as probabilidades (condicionais) são apresentadas na segunda coluna. É necessário destacar que a relação de paternidade é verdadeira por hipótese.

Pela definição de probabilidade condicional, a probabilidade conjunta é dada por:

$$
\begin{array}{r}
\operatorname{Pr}(\text { genótipo do filho, genótipo do pai, genótipo da mãe })= \\
\operatorname{Pr}(\text { genótipo do filho|genótipo do pai,genótipo da mãe }) * \\
\operatorname{Pr}(\text { genótipo do pai,genótipo da mãe })
\end{array}
$$

Como os pais podem ser quaisquer indivíduos na população, faz sentido utilizar a probabilidade de ocorrência do genótipo na população (tabela 4). 
Supondo que os genótipos dos pais sejam independentes, resulta:

$$
\begin{array}{r}
\operatorname{Pr}(\text { genótipo do filho, genótipo do pai, genótipo da mãe })= \\
\operatorname{Pr}(\text { genótipo do filho|genótipo do pai,genótipo da mãe }) * \\
\operatorname{Pr}(\text { genótipo do pai }) * \operatorname{Pr}(\text { genótipo da mãe })
\end{array}
$$

as probabilidades conjuntas resultantes são dadas na tabela 5 .

Com as probabilidades conjuntas, podemos calcular a probabilidade do genótipo do pai dado, por exemplo, que o filho tem genótipo $\left[A_{1} A_{1}\right]$ - o problema "inverso" - somando na conjunta, para cada possível genótipo do pai os casos em que genótipo do filho $=\left[A_{1} A_{1}\right]$ (marcados na tabela por I, II ou III) e re-normalizando os valores obtidos para que a soma das probabilidades dos genótipos do pai seja 1 (tabela 6).

A inferência feita no exemplo foi representada (ou apresentada) por meio de tabelas e operações de seleção e combinação de linhas destas. Existem representações gráficas para este tipo de inferência, por exemplo, Redes Bayesianas.

\subsection{Redes Bayesianas}

Redes Bayesianas são um instrumento para representação e modelagem de processos e inferência das variáveis do processo baseado em cálculo de probabilidade e inferência bayesiana. Nelas, processos são descritos em termos das variáveis aleatórias envolvidas e da influência entre elas, medida pela probabilidade condicional. A essa representação podem ser acrescentadas evidências e então inferir o valor de qualquer variável aleatória.

Embora o teorema em que se baseiam as Redes Bayesianas seja o próprio Teorema de Bayes, e o tipo de diagrama seja derivado dos grafos de influência propostos por Miler em 1976 [Miller et al., 1976], somente na década de 80, com o aumento da capacidade de processamento dos computadores, se tornaram viáveis as implementações de redes bayesianas, tornando possíveis softwares como o JavaBayes [Cozman,2001] e o Hugin [Andersen,1989].

Formalmente, uma rede bayesiana é um grafo dirigido e acíclico, $G$ onde cada nó $n o_{1}, n o_{2}, \ldots n o_{n}$ representa uma variável aleatória e cada aresta a influência entre as variáveis que conecta. Cada variável aleatória $n o_{i}$ é descrita pelos valores que pode assumir e suas respectivas probabilidades condicionadas aos eventos dos seus pais $p a\left(n o_{i}\right)$. 


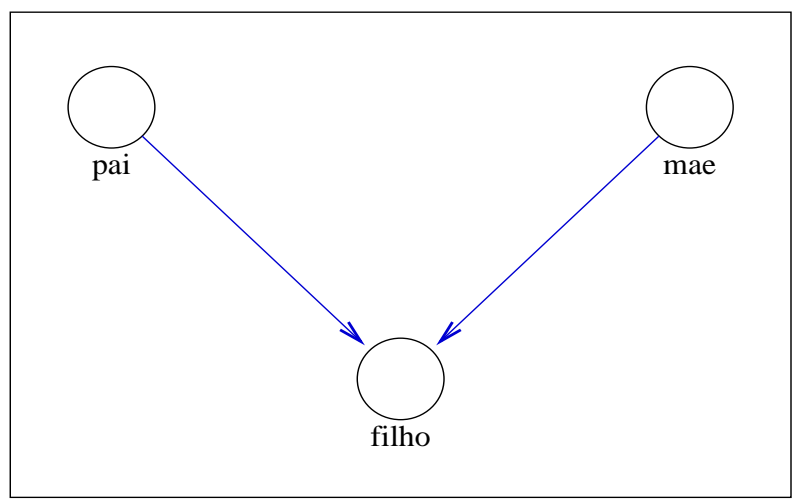

Figura 11: Rede Bayesiana de um Trio (pai, mãe e filho)

Introduzindo o exemplo do trio abordado na seção anterior no JavaBayes, temos a seguinte rede bayesiana (figura 11):

São três as variáveis aleatórias do problema, cada uma tem uma certa distribuição de probabilidade; então três tabelas contendo as distribuições devem ser fornecidas. O genótipo do filho é determinado pelo genótipo dos pais, como mostra a tabela 7, que por sua vez é uma maneira diferente de representar as mesmas probabilidades condicionais apresentadas na tabela 3 . Na primeira linha da tabela 7 são apresentados todos os genótipos possíveis do pai, na segunda, todos os genótipos possíveis da mãe, distribuídos de maneira que cada coluna represente uma de todas as combinações possíveis dos genótipos do pai e da mãe, ou seja, a primeira coluna representa pai com genótipo $\left[A_{1} A_{1}\right]$ e mãe com genótipo $\left[A_{1} A_{1}\right]$, a segunda pai com genótipo $\left[A_{1} A_{1}\right]$ e mãe com genótipo $\left[A_{1} A_{2}\right]$, a terceira pai com genótipo $\left[A_{1} A_{1}\right]$ mãe com genótipo $\left[A_{2} A_{2}\right]$, a quarta pai com genótipo $\left[A_{1} A_{2}\right]$, mãe com genótipo $\left[A_{1} A_{1}\right]$, a sétima pai com genótipo $\left[A_{2} A_{2}\right]$ e mãe com genótipo $\left[A_{1} A_{1}\right]$. Sempre as variáveis condicionantes são apresentadas nas colunas. As linhas seguintes apresentam os possíveis genótipos do filho e as suas probabilidades dados os genótipos dos pais. Na linha correspondente ao genótipo do filho $\left[A_{1} A_{1}\right]$, a primeira probabilidade é a probabilidade de dados pai e mãe com genótipo $\left[A_{1} A_{1}\right]$, o filho também apresentar genótipo $\left[A_{1} A_{1}\right]$. Na segunda, dados pais com genótipo $\left[A_{1} A_{1}\right]$ e $\left[A_{1} A_{2}\right]$, o filho apresentar genótipo $\left[A_{1} A_{2}\right]$ e assim por diante.

Conforme o exemplo, os pais pertencem a uma população cuja freqüência genotípica é conhecida, sendo esta informação relevante pois influencia a 
probabilidade do genótipo do filho, apresentada na tabela 4. Nesta, cada linha representada um genótipo possível, seguido de sua probabilidade na população.

O teorema que fundamenta as redes bayesianas diz que em uma rede bayesiana, pode-se calcular a probabilidade conjunta de todas as variáveis do processo, conforme provado em [Jensen,2001].

$$
\operatorname{Pr}(U)=\Pi_{i}\left(\operatorname{Pr}\left(A_{i}\right) \mid p a\left(A_{i}\right)\right)
$$

nele a probabilidade conjunta $\operatorname{Pr}(U)$ é calculada como o produtório das probabilidades das variáveis aleatórias $\left(A_{i}\right)$ condicionadas às probabilidades de seus pais $\left(p a\left(A_{i}\right)\right)$. No exemplo, utilizando o teorema acima, obtém-se $\operatorname{Pr}$ (genótipo do filho, genótipo do pai, genótipo da mãe) já apresentado no capítulo anterior na tabela 5 . Usando o teorema 4.2 :

$$
\begin{array}{r}
\operatorname{Pr}(U)=\operatorname{Pr}(\text { genótipo do filho, genótipo do pai, genótipo da mãe })= \\
\operatorname{Pr}(\text { genótipo do filho|genótipo do pai,genótipo da mãe }) * \\
\operatorname{Pr}(\text { genótipo do pai }) * \operatorname{Pr}(\text { genótipo da mãe })
\end{array}
$$

para o caso da primeira linha da tabela 5

$\operatorname{Pr}$ (genótipo do filho $=\left[A_{1} A_{1}\right]$, genótipo do pai $=\left[A_{1} A_{1}\right]$, genótipo da mãe $\left.=\left[A_{1} A_{1}\right]\right)=$ $\operatorname{Pr}\left(\right.$ genótipo do filho $=\left[A_{1} A_{1}\right] \mid$ genótipo do pai $=\left[A_{1} A_{1}\right]$, genótipo da mãe $\left.=\left[A_{1} A_{1}\right]\right) *$

$\operatorname{Pr}\left(\right.$ genótipo do pai $\left.=\left[A_{1} A_{1}\right]\right) * \operatorname{Pr}\left(\right.$ genótipo da mãe $\left.=\left[A_{1} A_{1}\right]\right)=1 * 0.3 * 0.3=0.09$

Calculada a probabilidade conjunta, introduzir evidências, ou seja, informar que alguns eventos ocorreram, corresponde a selecionar todos os casos em que esses eventos ocorrem e renormalizar, como feito no exemplo da seção anterior.

\subsection{Combinação dos resultados de vários experimentos}

É comum precisar combinar as probabilidades resultantes de várias realizações do experimento. Por exemplo, no caso da paternidade, vários loci são analisados e para cada um resulta um valor de probabilidade do indivíduo ser pai. Esses valores precisam ser combinados em um único que reflita a probabilidade do indivíduo ser pai, dados todos os loci. 
Pela interpretação subjetivista de probabilidade, a fórmula de Bayes é uma maneira de atualizar a opinião do estatístico a respeito da probabilidade de ocorrência de um evento.

$$
\begin{aligned}
\operatorname{Pr}(A \mid \Delta) & =\frac{\operatorname{Pr}(\Delta \mid A)}{\operatorname{Pr}(\Delta)} * \pi \\
\text { ou } & \\
\operatorname{Pr}(A \mid \Delta) & =\frac{\operatorname{Pr}(\Delta \mid A)}{\sum_{A} \operatorname{Pr}(\Delta \mid A) * P(A)} * \pi
\end{aligned}
$$

$\pi$ é chamada priori, a opinião do estatístico antes de conhecer os dados. Em geral, a determinação de uma priori adequada é difícil, opta-se então por consultar um especialista no processo em questão, ou utilizar uma priori que não favoreça de antemão algum dos eventos considerados, ou ainda apresentar como resultado a razão de verossimilhança, que é um valor que independe da priori.

$\Delta$ representa a informação obtida através da realização de um ou mais experimentos.

$A$ representa o evento de interesse - para o qual deseja-se inferir a probabilidade.

$\operatorname{Pr}(\Delta \mid A)$, às vezes denotado $L(A \mid \Delta)$ é chamada verossimilhança proporcionada a $A$ por $\Delta$, é a probabilidade de se observar os dados, $\Delta$, quando o resultado $A$ é conhecido.

O somatório $\sum_{A} \operatorname{Pr}(\Delta \mid A) * \operatorname{Pr}(A)$ é uma constante, dado o valor de $A$ de interesse. Pode ser visto como uma constante de normalização para que a soma das probabilidades para todos os eventos $A$ disjuntos possíveis dado $\Delta$ valha 1. Operacionalmente é comum que se calcule para cada evento todos os numeradores da fórmula de Bayes e então normalizar os numeradores.

Considere duas realizações independentes, no sentido estatístico, B e C, por exemplo dois loci, e a variável aleatória cuja probabilidade queremos atualizar - o indivíduo ser pai. Se $\Delta$ representar a informação resultante das duas realizações, $\Delta=(B, C)$, segundo a fórmula de Bayes:

$$
\begin{aligned}
\operatorname{Pr}(A \mid B, C) & =\frac{\operatorname{Pr}(B, C \mid A)}{\operatorname{Pr}(B, C)} * \pi= \\
& =\frac{\operatorname{Pr}(B \mid A) * \operatorname{Pr}(C \mid A)}{\operatorname{Pr}(B) * \operatorname{Pr}(C)} * \pi=
\end{aligned}
$$




$$
=\frac{\operatorname{Pr}(B \mid A)}{\operatorname{Pr}(B)} * \frac{\operatorname{Pr}(C \mid A)}{\operatorname{Pr}(C)} * \pi
$$

A forma final corresponde a aplicar a fórmula seqüencialmente para cada uma das realizações e obter a probabilidade a posteriori. Esta carrega a opinião inicial sobre a variável aleatória - a priori. Às vezes é mais conveniente saber apenas o que os experimentos informam, o que é apresentado pela razão de Verossimilhança.

Suponha um evento $H$ que assume um dos valores $\{$ Verdadeiro, Falso e dados representados por $\Delta$, de forma que:

$$
\begin{gathered}
\operatorname{Pr}(H \mid \Delta)=\frac{L(H \mid \Delta)}{\operatorname{Pr}(H)} * \pi \\
\frac{\operatorname{Pr}(H=\text { Verdadeiro } \mid \Delta)}{\operatorname{Pr}(H=\text { Falso } \mid \Delta)}=\frac{L(H=\text { Verdadeiro } \mid \Delta)}{L(H=\text { Falso } \mid \Delta)} * \frac{\pi}{1-\pi}
\end{gathered}
$$

chamamos razão de verossimilhança a razão

$$
\frac{L(H=\text { Verdadeiro } \mid \Delta)}{L(H=\text { Falso } \mid \Delta)}
$$

que representa a contribuição dos dados em favor de $H=$ Verdadeiro. A razão de verossimilhança tem duas características importantes:

- Torna-se desnecessário calcular o denominador da fórmula de Bayes, que se cancela no cálculo da razão de verossimilhança.

- A razão de verossimilhança independe da priori, podendo ser considerada uma representação da informação que os dados oferecem, sem outras influências.

A razão de verossimilhança combinando várias realizações pode ser obtida a partir da aplicação seqüencial da fórmula de Bayes e corresponde ao produtório das razões de verossimilhança para cada realização. 


\begin{tabular}{|c|c|}
\hline $\operatorname{trio}=($ pai, mãe , filho $)$ & $\operatorname{Pr}($ genótipo do filho|genótipo do pai, genótipo da mãe) \\
\hline$\left(\left[A_{1} A_{1}\right],\left[A_{1} A_{1}\right],\left[A_{1} A_{1}\right]\right)$ & 1 \\
\hline$\left(\left[A_{1} A_{1}\right],\left[A_{1} A_{1}\right],\left[A_{1} A_{2}\right]\right)$ & 0 \\
\hline$\left(\left[A_{1} A_{1}\right],\left[A_{1} A_{1}\right],\left[A_{2} A_{2}\right]\right)$ & 0 \\
\hline$\left(\left[A_{1} A_{1}\right],\left[A_{1} A_{2}\right],\left[A_{1} A_{1}\right]\right)$ & $1 / 2$ \\
\hline$\left(\left[A_{1} A_{1}\right],\left[A_{1} A_{2}\right],\left[A_{1} A_{2}\right]\right)$ & $1 / 2$ \\
\hline$\left(\left[A_{1} A_{1}\right],\left[A_{1} A_{2}\right],\left[A_{2} A_{2}\right]\right)$ & 0 \\
\hline$\left(\left[A_{1} A_{1}\right],\left[A_{2} A_{2}\right],\left[A_{1} A_{1}\right]\right)$ & 0 \\
\hline$\left(\left[A_{1} A_{1}\right],\left[A_{2} A_{2}\right],\left[A_{1} A_{2}\right]\right)$ & 1 \\
\hline$\left(\left[A_{1} A_{1}\right],\left[A_{2} A_{2}\right],\left[A_{2} A_{2}\right]\right)$ & 0 \\
\hline$\left(\left[A_{1} A_{2}\right],\left[A_{1} A_{1}\right],\left[A_{1} A_{1}\right]\right)$ & $1 / 2$ \\
\hline$\left(\left[A_{1} A_{2}\right],\left[A_{1} A_{1}\right],\left[A_{1} A_{2}\right]\right)$ & $1 / 2$ \\
\hline$\left(\left[A_{1} A_{2}\right],\left[A_{1} A_{1}\right],\left[A_{2} A_{2}\right]\right)$ & 0 \\
\hline$\left(\left[A_{1} A_{2}\right],\left[A_{1} A_{2}\right],\left[A_{1} A_{1}\right]\right)$ & $1 / 4$ \\
\hline$\left(\left[A_{1} A_{2}\right],\left[A_{1} A_{2}\right],\left[A_{1} A_{2}\right]\right)$ & $1 / 2$ \\
\hline$\left(\left[A_{1} A_{2}\right],\left[A_{1} A_{2}\right],\left[A_{2} A_{2}\right]\right)$ & $1 / 4$ \\
\hline$\left(\left[A_{1} A_{2}\right],\left[A_{2} A_{2}\right],\left[A_{1} A_{1}\right]\right)$ & 0 \\
\hline$\left(\left[A_{1} A_{2}\right],\left[A_{2} A_{2}\right],\left[A_{1} A_{2}\right]\right)$ & $1 / 2$ \\
\hline$\left(\left[A_{1} A_{2}\right],\left[A_{2} A_{2}\right],\left[A_{2} A_{2}\right]\right)$ & $1 / 2$ \\
\hline$\left(\left[A_{2} A_{2}\right],\left[A_{1} A_{1}\right],\left[A_{1} A_{1}\right]\right)$ & 0 \\
\hline$\left(\left[A_{2} A_{2}\right],\left[A_{1} A_{1}\right],\left[A_{1} A_{2}\right]\right)$ & 1 \\
\hline$\left(\left[A_{2} A_{2}\right],\left[A_{1} A_{1}\right],\left[A_{2} A_{2}\right]\right)$ & 0 \\
\hline$\left(\left[A_{2} A_{2}\right],\left[A_{1} A_{2}\right],\left[A_{1} A_{1}\right]\right)$ & 0 \\
\hline$\left(\left[A_{2} A_{2}\right],\left[A_{1} A_{2}\right],\left[A_{1} A_{2}\right]\right)$ & $1 / 2$ \\
\hline$\left(\left[A_{2} A_{2}\right],\left[A_{1} A_{2}\right],\left[A_{2} A_{2}\right]\right)$ & $1 / 2$ \\
\hline$\left(\left[A_{2} A_{2}\right],\left[A_{2} A_{2}\right],\left[A_{1} A_{1}\right]\right)$ & 0 \\
\hline$\left(\left[A_{2} A_{2}\right],\left[A_{2} A_{2}\right],\left[A_{1} A_{2}\right]\right)$ & 0 \\
\hline$\left(\left[A_{2} A_{2}\right],\left[A_{2} A_{2}\right],\left[A_{2} A_{2}\right]\right)$ & 1 \\
\hline
\end{tabular}

Tabela 3: $\operatorname{Pr}$ (gen_filho | gen_pai, gen_mae)

\begin{tabular}{c|c} 
genótipo & $\operatorname{Pr}($ genótipo $)$ \\
\hline$\left.\left[A_{1} A_{1}\right]\right)$ & 0.3 \\
$\left.\left[A_{1} A_{2}\right]\right)$ & 0.5 \\
$\left.\left[A_{2} A_{2}\right]\right)$ & 0.2 \\
\hline
\end{tabular}

Tabela 4: Freqüências dos genótipos na população 


\begin{tabular}{l|c|c} 
trio $=($ pai, mãe, filho $)$ & $\operatorname{Pr}($ genótipo do filho, genótipo do pai, genótipo da mãe $)$ & \\
\hline$\left(\left[A_{1} A_{1}\right],\left[A_{1} A_{1}\right],\left[A_{1} A_{1}\right]\right)$ & 0.09 & I \\
$\left(\left[A_{1} A_{1}\right],\left[A_{1} A_{1}\right],\left[A_{1} A_{2}\right]\right)$ & 0 & \\
$\left(\left[A_{1} A_{1}\right],\left[A_{1} A_{1}\right],\left[A_{2} A_{2}\right]\right)$ & 0 & \\
$\left(\left[A_{1} A_{1}\right],\left[A_{1} A_{2}\right],\left[A_{1} A_{1}\right]\right)$ & 0.075 & \\
$\left(\left[A_{1} A_{1}\right],\left[A_{1} A_{2}\right],\left[A_{1} A_{2}\right]\right)$ & 0.075 & \\
$\left(\left[A_{1} A_{1}\right],\left[A_{1} A_{2}\right],\left[A_{2} A_{2}\right]\right)$ & 0 & I \\
$\left(\left[A_{1} A_{1}\right],\left[A_{2} A_{2}\right],\left[A_{1} A_{1}\right]\right)$ & 0 & \\
$\left(\left[A_{1} A_{1}\right],\left[A_{2} A_{2}\right],\left[A_{1} A_{2}\right]\right)$ & 0.06 & II \\
$\left(\left[A_{1} A_{1}\right],\left[A_{2} A_{2}\right],\left[A_{2} A_{2}\right]\right)$ & 0 & \\
$\left(\left[A_{1} A_{2}\right],\left[A_{1} A_{1}\right],\left[A_{1} A_{1}\right]\right)$ & 0.075 & \\
$\left(\left[A_{1} A_{2}\right],\left[A_{1} A_{1}\right],\left[A_{1} A_{2}\right]\right)$ & 0.075 & \\
$\left(\left[A_{1} A_{2}\right],\left[A_{1} A_{1}\right],\left[A_{2} A_{2}\right]\right)$ & 0 & \\
$\left(\left[A_{1} A_{2}\right],\left[A_{1} A_{2}\right],\left[A_{1} A_{1}\right]\right)$ & 0.0625 & \\
$\left(\left[A_{1} A_{2}\right],\left[A_{1} A_{2}\right],\left[A_{1} A_{2}\right]\right)$ & 0.125 & \\
$\left(\left[A_{1} A_{2}\right],\left[A_{1} A_{2}\right],\left[A_{2} A_{2}\right]\right)$ & 0.0625 & \\
$\left(\left[A_{1} A_{2}\right],\left[A_{2} A_{2}\right],\left[A_{1} A_{1}\right]\right)$ & 0 & \\
$\left(\left[A_{1} A_{2}\right],\left[A_{2} A_{2}\right],\left[A_{1} A_{2}\right]\right)$ & 0.05 & \\
$\left(\left[A_{1} A_{2}\right],\left[A_{2} A_{2}\right],\left[A_{2} A_{2}\right]\right)$ & 0.05 & \\
$\left(\left[A_{2} A_{2}\right],\left[A_{1} A_{1}\right],\left[A_{1} A_{1}\right]\right)$ & 0 & \\
$\left(\left[A_{2} A_{2}\right],\left[A_{1} A_{1}\right],\left[A_{1} A_{2}\right]\right)$ & 0.06 & \\
$\left(\left[A_{2} A_{2}\right],\left[A_{1} A_{1}\right],\left[A_{2} A_{2}\right]\right)$ & 0 & \\
$\left(\left[A_{2} A_{2}\right],\left[A_{1} A_{2}\right],\left[A_{1} A_{1}\right]\right)$ & 0 & \\
$\left(\left[A_{2} A_{2}\right],\left[A_{1} A_{2}\right],\left[A_{1} A_{2}\right]\right)$ & 0.05 & \\
$\left(\left[A_{2} A_{2}\right],\left[A_{1} A_{2}\right],\left[A_{2} A_{2}\right]\right)$ & 0.05 & \\
$\left(\left[A_{2} A_{2}\right],\left[A_{2} A_{2}\right],\left[A_{1} A_{1}\right]\right)$ & 0 & \\
$\left(\left[A_{2} A_{2}\right],\left[A_{2} A_{2}\right],\left[A_{1} A_{2}\right]\right)$ & 0 & \\
$\left(\left[A_{2} A_{2}\right],\left[A_{2} A_{2}\right],\left[A_{2} A_{2}\right]\right)$ & 0.04 & \\
\hline & &
\end{tabular}

Tabela 5: $\quad$ Probabilidade Conjunta para Trio -

$\operatorname{Pr}$ (genótipo do filho, genótipo do pai, genótipo da mãe) 


\begin{tabular}{c|c|c} 
genótipo do pai & $\sum$ & $\operatorname{Pr}($ genótipo do pai $)$ \\
\hline$\left.\left[A_{1} A_{1}\right]\right)$ & 0.165 & 0.545 \\
$\left.\left[A_{1} A_{2}\right]\right)$ & 0.1375 & 0.455 \\
$\left.\left[A_{2} A_{2}\right]\right)$ & 0.0 & 0.0 \\
\hline
\end{tabular}

Tabela 6: Inversão da probabilidade - Probabilidade do genótipo do pai dado genótipo do filho $=\left[A_{1} A_{1}\right]$

\begin{tabular}{c|c|c|c|c|c|c|c|c|c|} 
gen_pai & \multicolumn{3}{|c|}{ A1A1 } & \multicolumn{3}{c|}{ A1A2 } & \multicolumn{3}{c|}{ A2A2 } \\
gen_mae & A1A1 & A1A2 & A2A2 & A1A1 & A1A2 & A2A2 & A1A1 & A1A2 & A2A2 \\
\hline A1A1 & 1 & 0.5 & 0 & 0.5 & 0.25 & 0 & 0 & 0 & 0 \\
\hline A1A2 & 0 & 0.5 & 1 & 0.5 & 0.5 & 0.5 & 0.5 & 0.5 & 0 \\
\hline A2A2 & 0 & 0 & 0 & 0 & 0.25 & 0.5 & 0.5 & 0.5 & 1 \\
\hline
\end{tabular}

Tabela 7: p(gen_filho | gen_pai, gen_mae) 


\subsection{Teste de Hipóteses}

O último tópico que precisa ser coberto nesta revisão é o de teste de hipóteses, que consiste em usar uma medida probabilística que indica se a hipótese testada é ou não verdadeira. Nesta situação a hipótese é chamada hipótese nula é notada $H_{0}$. Seu complemento é chamado hipótese alternativa e notado $H_{1}$.

O primeiro teste de hipótese que se apresenta nesta tese é o do reclamante ser (ou não) filho do pai presumido:

$$
\begin{gathered}
H_{0} \text { : o reclamante é filho } \\
H_{1} \text { : o reclamante não é filho }
\end{gathered}
$$

Este problema pode ser simplificado e escrito como "determinar a probabilidade de que o pai presumido seja o pai verdadeiro", pois nas seções anteriores mostrou-se como estimar o genótipo do pai verdadeiro. Este teste pode ser feito usando uma rede bayesiana, pois as variáveis - "genótipo do pai verdadeiro", "genótipo do pai presumido" e "pai verdadeiro é igual a pai presumido" - são discretas e enumeráveis. O problema "direto" é "dados o genótipo do pai verdadeiro e que o pai verdadeiro é (ou não) igual ao pai presumido, qual é o genótipo do pai presumido". A solução é "inverter" a probabilidade, calculando a probabilidade do pai presumido ser igual ao pai verdadeiro - o que a rede bayesiana da figura 12 faz.

O pai presumido é um indivíduo da população, logo os genótipos ocorrem de acordo com a freqüência populacional, por exemplo a apresentada na tabela 8. Caso o pai verdadeiro seja igual ao pai presumido, seus genótipos têm que ser iguais, caso contrário o pai verdadeiro também é um indivíduo da população, conforme a tabela 9. Quanto aos indivíduos serem ou não iguais, em princípio não há motivo para favorecer uma ou outra alternativa, o que é representado na tabela 10.

\begin{tabular}{c|c|} 
& $\operatorname{Pr}$ (pai presumido) \\
\hline A1A1 & 0.3 \\
\hline A1A2 & 0.4 \\
\hline A2A2 & 0.3 \\
\hline
\end{tabular}

Tabela 8: $\operatorname{Pr}$ (pai presumido) 


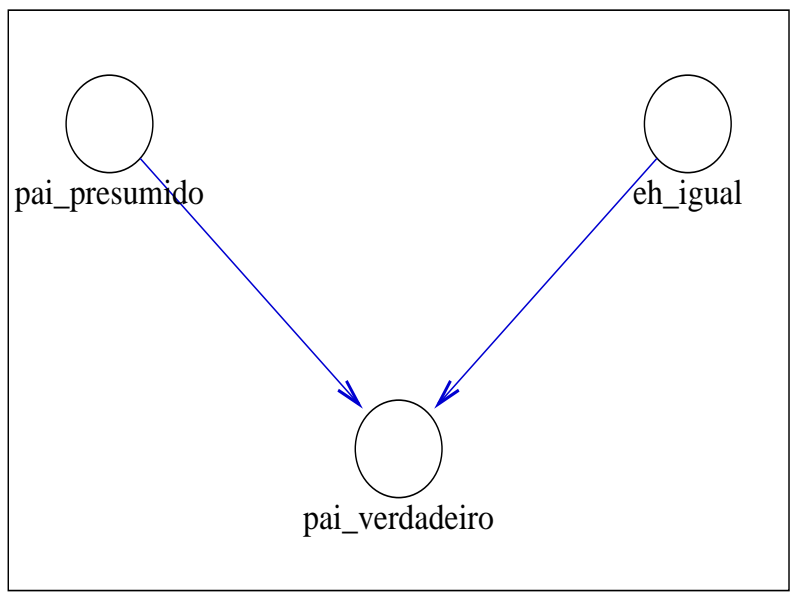

Figura 12: Teste da hipótese de que o pai presumido é o pai verdadeiro.

\begin{tabular}{c|c|c|c|c|c|c|} 
gen pai verdadeiro & \multicolumn{2}{|c|}{ A1A1 } & \multicolumn{2}{|c|}{ A1A2 } & \multicolumn{2}{|c|}{ A2A2 } \\
é igual & V & F & V & F & V & F \\
\hline A1A1 & 1 & 0.3 & 0 & 0.3 & 0 & 0.3 \\
\hline A1A2 & 0 & 0.4 & 1 & 0.4 & 0 & 0.4 \\
\hline A2A2 & 0 & 0.3 & 0 & 0.3 & 1 & 0.3 \\
\hline
\end{tabular}

Tabela 9: $\operatorname{Pr}$ (pai verdadeiro | pai presumido, eh igual)

A intuição sobre o funcionamento do teste pode ser obtida se considerarmos o evento $A$ como "os genótipos são iguais $\left(G_{1}=G_{2}\right)$ ", o evento $B$ como "os indivíduos são iguais $\left(i_{1}=i_{2}\right)$ " e o evento complementar $B^{c}$ como "os indivíduos são diferentes $\left(i_{1} \neq i_{2}\right)$ ". Pela regra de Bayes

$$
\operatorname{Pr}(B \mid A)=\frac{\operatorname{Pr}(A \mid B)}{\operatorname{Pr}(A)} * \operatorname{Pr}(B)
$$

e

$$
\operatorname{Pr}\left(B^{c} \mid A\right)=\frac{\operatorname{Pr}\left(A \mid B^{c}\right)}{\operatorname{Pr}(A)} * \operatorname{Pr}\left(B^{c}\right)
$$

considerando que a priori nenhuma das alternativas deve ser favorecida então $\operatorname{Pr}(B)=\operatorname{Pr}\left(B^{c}\right)$. Também sabe-se que $\operatorname{Pr}\left(B^{c} \mid A\right)=1-\operatorname{Pr}(B \mid A)$. Com um 


\begin{tabular}{c|c|} 
& $\operatorname{Pr}($ eh igual $)$ \\
\hline $\mathrm{V}$ & 0.5 \\
\hline $\mathrm{F}$ & 0.5 \\
\hline
\end{tabular}

Tabela 10: $\operatorname{Pr}($ eh igual $)$

pouco de manipulação chega-se a:

$$
\operatorname{Pr}(B \mid A)=\frac{\operatorname{Pr}(A \mid B)}{\operatorname{Pr}\left(A \mid B^{c}\right)+\operatorname{Pr}(A \mid B)}
$$

sabe-se que a probabilidade dos genótipos serem iguais dado que os indivíduos são iguais é $1(\operatorname{Pr}(A \mid B)=1)$ e que a probabilidade dos genótipos serem iguais dado que os indivíduos são diferentes é a probabilidade de se sortear um indivíduo da população e este ter o genótipo esperado, ou seja, a freqüência do genótipo na população $\operatorname{Pr}\left(A \mid B^{c}\right)=f_{G}$. Finalmente

$$
\operatorname{Pr}(B \mid A)=\frac{1}{f_{G}+1}
$$

esta fórmula mostra quantitativamente algo que a intuição diz: "quanto mais raro o genótipo na população maior a probabilidade de que o demandado seja o pai biológico pois é menos provável que um indivíduo tomado ao acaso tenha esse genótipo. Conversamente, quanto mais comum o genótipo na população menor é a probabilidade do demandado ser o pai biológico pois é mais provável que um indivíduo tomado ao acaso tenha esse genótipo."

Este ponto será importante para a comparação entre o modelo proposto e o modelo de referência.

Um outro teste semelhante que precisa ser realizado é aquele em que se deseja testar tanto o vínculo de paternidade quanto o de maternidade. Isto pode ocorrer quando ambos os genitores falecem e neste caso genótipos de avós, tios e irmãos reconhecidos do demandante são usados para o cálculo, resultando em um heredograma extenso. A generalização do teste é simples e a fim de simplificar a figura 13, a informação sobre os parentes testados será omitida e apresentar-se-á apenas o trio - os dois demandados e o demandante.

A variável de decisão continua sendo única, embora a hipótese testada seja se os demandados são os genitores ou não, o que se consegue comparando os genótipos do pai presumido e do pai verdadeiro e comparando os da mãe presumida e da mãe verdadeira, como já explicado para o caso do demandado ser o pai. 


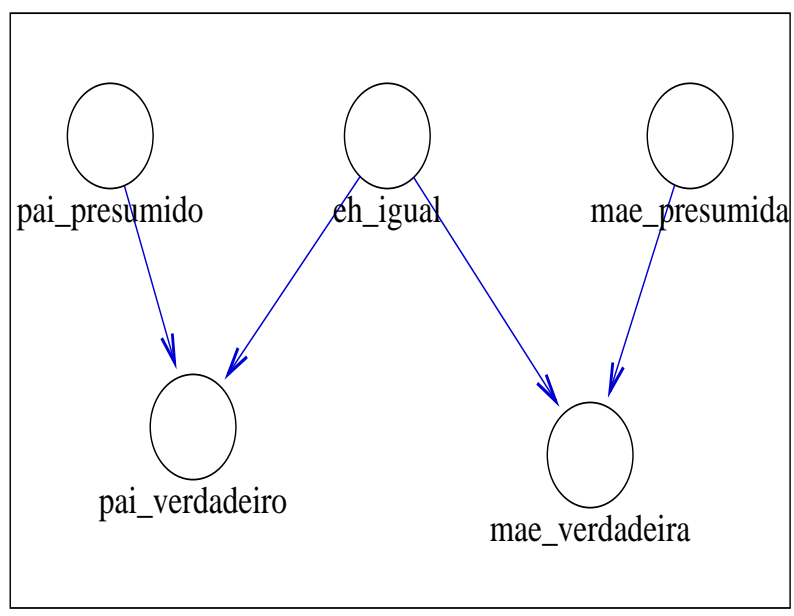

Figura 13: Teste conjunto de paternidade e maternidade [conjoint]

A terceira hipótese a testar é de um tipo diferente das anteriores. Consiste em testar se o modelo baseado apenas em herança mendeliana é adequado para o cálculo de probabilidade de paternidade. Conforme mencionado no capítulo 2, há fatores, como mutação e seleção natural que perturbam as proporções dos genótipos na população, com impacto na probabilidade de paternidade. Para evitar essa perturbação, no procedimento de laboratório são utilizadas regiões do cromossomo que "não têm função" - marcadores moleculares ideais. No procedimento estatístico pode se testar se o locus está em equilíbrio de Hardy-Weinberg.

Hardy e Weinberg em 1908 [Hardy, 1908], [Weinberg, 1908] notaram que na ausência de mutação e pressões seletivas, num processo de herança segundo as Leis de Mendel, as freqüências alélicas e as genotípicas obedecem à seguinte relação:

$$
\begin{gathered}
f_{A_{1}, A_{2}}=2 * f_{A_{1}} * f_{A_{2}},\left(A_{1} \neq A_{2}\right) \\
f_{A_{1}, A_{2}}=f_{A_{1}}^{2}=f_{A_{2}}^{2},\left(A_{1}=A_{2}\right)
\end{gathered}
$$

e que essas freqüências se mantém nesse equilíbrio ao longo do tempo. 
Por completude (pois o resultado que se segue não será utilizado na tese), eles também notaram que se houver alguma perturbação temporária nesse equilíbrio, uma geração após essa perturbação cessar, estabelece-se um novo equilíbrio com novas freqüências.

Considerando que num teste de paternidade são periciados ao menos pai e filho - ou duas gerações - torna-se necessário que o equilíbrio se verifique ao longo do tempo.

Em uma população, para um locus há uma quantidade enumerável de genótipos possíveis. Não é possível medir os genótipos de todos os indivíduos da população, mas pode-se medir os genótipos de uma amostra da população. Numa analogia com uma urna cheia de bolas coloridas, que representa a população, onde cada bola representa um indivíduo e cada cor um genótipo, com a amostra de bolas (indivíduos) pode se inferir as freqüências das cores (genótipos) na população, que são representadas por $f_{A_{1}, A_{2}}$ no que nesta tese convencionou-se chamar de relação (de Hardy-Weinberg).

Problemas de bolas e urnas são temas freqüentes em probabilidade e estatística e contam com modelos consolidados. Em estatística Bayesiana, um desses modelos considera que as freqüências têm distribuição Beta e a verossimilhança tem distribuição Binomial no caso particular em que as bolas podem ter uma de duas cores. Quando a escolha de cores é mais ampla, as generalizações dessas distribuições são a Dirichlet e a Multinomial, respectivamente. Na aplicação da regra de Bayes para atualização da distribuição das freqüências genotípicas, caso a priori tenha distribuição Dirichlet e a verossimilhança tenha distribuição Multinomial, a posteriori tem distribuição Dirichlet. Uma variável aleatória $\pi$ de dimensão $k$ onde $\pi_{i}>0$ e $\sum_{i} \pi_{i}=1$ tem distribuição Dirichlet (nota-se $\pi \tilde{D} i r_{k}(d)$ ) se sua densidade é:

$$
f(\pi)=\Gamma\left(\sum_{i=1}^{k} d_{i}\right) \Pi_{i=1}^{k}\left(\frac{\pi_{i}^{d_{i}-1}}{\Gamma\left(d_{i}\right)}\right)
$$

onde $d$ é um vetor de dimensão $k$ de números reais positivos e $\Gamma(a)$ é a função Gama no ponto a.

Quando $d=1$ a variável aleatória $\pi$ tem distribuição uniforme.

A verossimilhança é escrita como

$$
L(\pi \mid x)=\Pi_{i} \pi_{i}^{x_{i}}
$$

onde $\sum \pi_{i}=1$ 
Pela regra de Bayes, a posteriori tem distribuição

$$
f_{x} \propto L(\pi \mid x) f(\pi)
$$

. Caso a priori seja uniforme, a densidade á posteriori tem a forma

$$
f_{x}(\pi) \propto \Pi_{i=1}^{k} * \pi_{i}^{d_{i}}
$$

Uma metodologia bayesiana para teste de hipóteses é o "Teste de hipóteses Genuinamente Bayesiano" (FBST - Full Bayesian Significance Test) criado por Pereira e Stern em 1999 [Pereira Stern, 1999]. Neste artigo seminal, um dos exemplos de aplicação do FBST é o teste do equilíbrio de Hardy-Weinberg em um locus com dois alelos. Neste caso são possíveis três genótipos, cujas freqüências somam um; desta forma a freqüência de um dos genótipos é função das outras duas, conseqüentemente a densidade pode ser apresentada em um gráfico de três dimensões (figura 14).

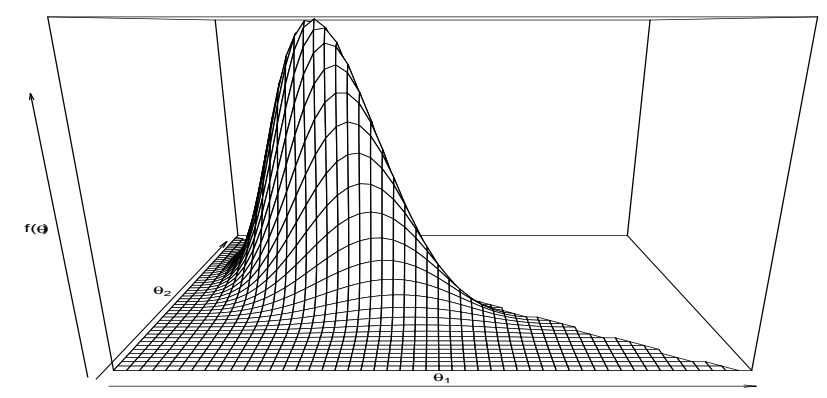

Figura 14: Densidade para HWE dois alelos

O teste consiste em dois passos: achar o máximo da densidade na hipótese e calcular a probabilidade do conjunto de eventos cujas densidades são maiores que o máximo na hipótese. Essa probabilidade, ou evidência contra a hipótese, mede quão longe se está da hipótese.

A dimensão do espaço do teste direto é igual a quantidade de genótipos possíveis no locus testado. Num locus com $m$ alelos, $m(m+1) / 2$ genótipos são 


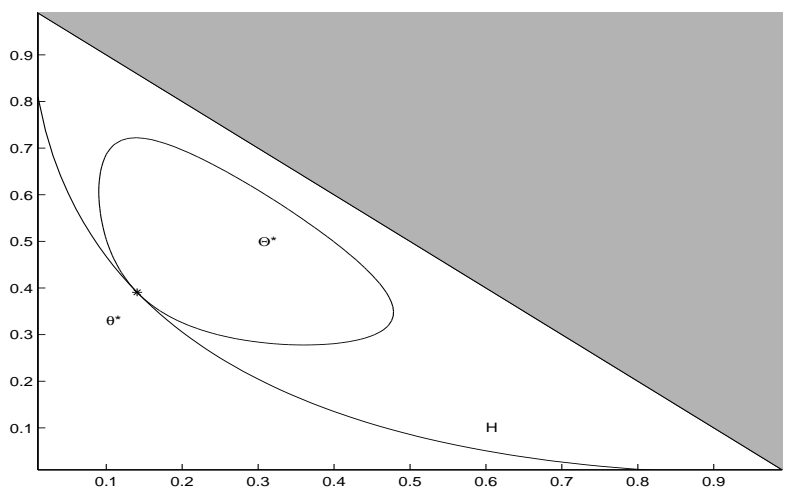

Figura 15: Espaço paramétrico, hipótese e conjunto de máxima surpresa relativa para o teste do equilíbrio de Hardy-Weinberg

Considerando as curvas de nível de $f(\theta)$, a curva marcada com $\mathrm{H}$ é o conjunto de pontos que satisfaz à hipótese, $\theta *$ em $\mathrm{H}$ é o ponto de máximo da densidade na hipótese $\Theta *$ é o conjuto de maior surpresa relativa.

possíveis. Loci com cerca de vinte alelos são comuns, e requerem testes diretos de dimensão maior que duzentos, que podem trazer dificuldades computacionais. Uma maneira de lidar com isso é apresentada em [Pereira et al.,2006].

Propõe-se que o teste (FBST) seja aplicado sequencial e hierarquicamente, na base de um contra o restante:

1. selecione o alelo de menor freqüência;

2. aplique o FBST testando o alelo selecionado contra os restantes;

3. remova o alelo testado;

4. repita o procedimento a partir do passo 1 ;

Considera-se o locus em desequilíbrio se a evidência contra a hipótese para algum dos loci for muito grande.

Desta forma aplicam-se $m-1$ testes sobre dois alelos em lugar de aplicar um único teste sobre $m(m+1) / 2$ alelos.

Segue-se agora para a apresentação do modelo proposto. 


\section{Referências}

[Pereira Stern, 1999] PEREIRA, CAB, STERN JM - Evidence and Credibility: Ful Bayesian Significance Test for precise hypotheses. - Entropy 1: 104-115

[Pereira et al.,2006]

PEREIRA,CAB, NAKANO F, STERN JM, WHITTLE M. - Genuine Bayesian Multiallelic significance test for the Hardy-Weinberg Equilibrium Law - Genetics and Molecular Research, In print.

[Kolmogorov,1933]

KOLMOGOROV, A.N. - Grundbegriffe der Wahrscheinlichkeitsrechnung. - 1933, Springer Berlin

[Cox, 1961]

COX,R.T. - The Algebra of Probable InferenceJohns Hopkins University Press, Baltimore, MD, (1961).

[Bayes, 1763]

BAYES - An Essay Towards Solving a Problem in the Doctrine of Chances. - Philosophical Transactions of the Royal Society of London. (1763).

[Miller et al., 1976]

MILlER, A. C., M. M. MERKHOFER, R. A. HOWARD, J. E. MATHESON and T. R. RICE (1976) - Automated Aids for Decision Making: Development of a Decision Morphology - 1976 Stanford Research Institute.

[Cozman,2001]

COZMAN, F. G. - JavaBayes User Manual http://www.usp.br/fgcozman/home.html 2001 University of São Paulo - Brasil

[DeGroot,2002 ]

DEGROOT, MORRIS H. and SCHERVISH, MARK J. - Probability and Statistics - 2002, Addison Wesley 
[Jensen,2001]

[Andersen,1989]

[Stigler, 1994]

[Hardy, 1908]

[Weinberg, 1908]

[Wikipedia]
JENSEN, F.V.- Bayesian Networks and Decision Graphs

2001 - Springer

ANDERSEN, S. K., OLESEN, K. G., JENSEN, F. V. and JENSEN, F. -Hugin: a shell for building Bayesian belief universes for expert systems - 1989, Proceedings of the 11th International Joint Conference on Artificial Intelligence, pages 1080-1085.

STIGLER, STEPHEN M. - The History of Statistics - 1986, Harvard University

HARDY, G. H. - Mendelian proportions in a mixed population. Science 28: 49-50. 1908

WEINBERG, W. Über den Nachweis der Vererbung beim Menschen. - Jahreshefte des Vereins fr vaterlndische Naturkunde in Wrttemberg 64: 368-382. 1908

- Wikipedia - The Free Encyclopedia http://www.wikipedia.org 


\section{Modelo}

A partir das ferramentas em probabilidade e estatística apresentadas no capítulo anterior, será proposto o modelo para cálculo de probabilidade de paternidade. Será também apresentado um modelo de referência e a relação entre os dois modelos. Ao final do capítulo será mostrado um exemplo em que o resultado do modelo proposto é diferente do resultado do modelo de referência.

\subsection{Modelo Proposto}

No capítulo anterior, para ilustrar conceitos em cálculo de probabilidade e em redes bayesianas foram usados exemplos envolvendo trios (pai, mãe e filho) em que a relação de paternidade é verdadeira por hipótese. Os elementos apresentados no trio - indivíduos, que são representados por seus locus e vínculos de paternidade - são suficientes para descrever qualquer genealogia. Com isto, descrever genealogias complexas, seja por redes bayesianas, seja por uma linguagem de programação, reduz-se a aplicação desses elementos simples.

A esses elementos é necessário acrescentar a taxa de mutação pois os marcadores genéticos utilizados têm altas taxas de mutação. Cabe ressaltar que entende-se aqui mutação como um evento que "transforma" a medida que indica um alelo numa medida que indica um outro. Sob esse entendimento, taxa de mutação é a probabilidade do "alelo original" se transformar no "alelo mutado" - Pr(alelo mutado|alelo original). O alelo original é um dos dois presentes no genitor e o alelo mutado é o alelo que o filho apresenta em seu genótipo. A rede bayesiana resultante para um trio é mostrada na figura 16 .

Resta agora inserir o teste da hipótese de paternidade apresentado na seção 4 do Capítulo 3, resultando na rede bayesiana para o cálculo da probabilidade de paternidade mostrada na figura 17. A fim de agilizar a leitura, a figura é seguida pelas tabelas de probabilidade condicional relativas a cada variável aleatória (nó) e explicações pertinentes, embora tabelas com as mesmas funções já tenham sido apresentadas nos capítulos anteriores. 


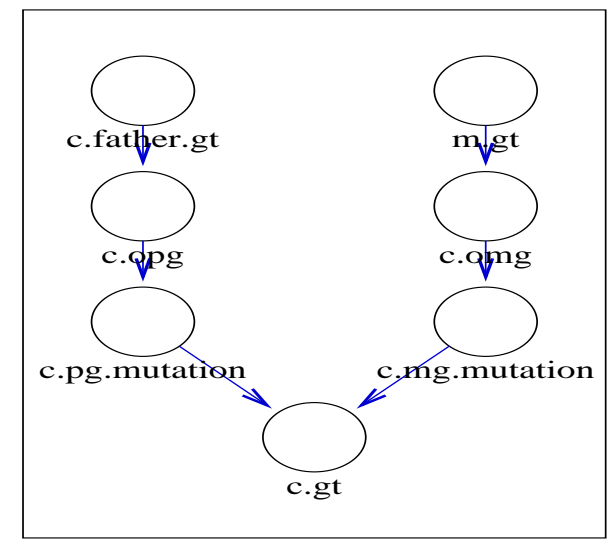

Figura 16: Trio com mutação

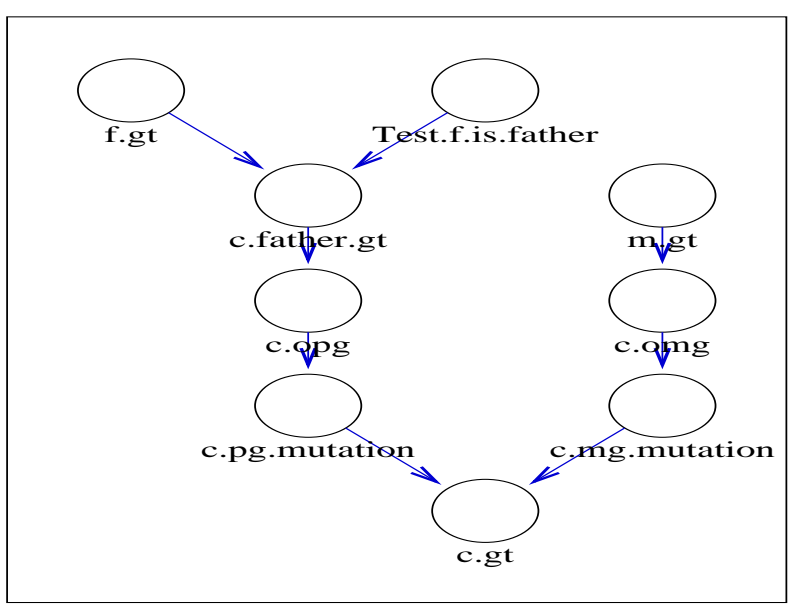

Figura 17: Trio com teste da hipótese de paternidade 


\begin{tabular}{c|c|} 
& $\operatorname{Pr}(f . g t)$ \\
\hline S10.S10 & 0.1 \\
\hline S10.S12 & 0.2 \\
\hline S10.SX & 0.3 \\
\hline S12.S12 & 0.05 \\
\hline S12.SX & 0.15 \\
\hline SX.SX & 0.2 \\
\hline
\end{tabular}

Tabela 11: $\operatorname{Pr}(f . g t)$ e $\operatorname{Pr}(m . g t)$

Pai presumido e mãe são indivíduos da população. Seus genótipos seguem as freqüências populacionais. A tabela apresenta os seis genótipos possíveis e suas freqüências.

\begin{tabular}{c|c|c|c|c|c|c|} 
& S10.S10 & S10.S12 & S10.SX & S12.S12 & S12.SX & SX.SX \\
\hline S10 & 1 & 0.5 & 0.5 & 0 & 0 & 0 \\
\hline S12 & 0 & 0.5 & 0 & 1 & 0.5 & 0 \\
\hline SX & 0 & 0 & 0.5 & 0 & 0.5 & 1 \\
\hline
\end{tabular}

Tabela 12: $\operatorname{Pr}($ c.omg $\mid$ m.gt $)$ e $\operatorname{Pr}($ c.opg $\mid$ c.father.gt $)$

Dado o genótipo do genitor - cujos valores possíveis estão na primeira linha da tabela, um dos alelos - cujos valores possíveis estão na primeira coluna da tabela - é transmitido ao filho com a probabilidade dada na intersecção entre linha e coluna. Por exemplo, se o genótipo do genitor é S10.S12, a menos de mutação, é passado para o filho ou o alelo S10 ou o S12, com probabilidade 0.5

\begin{tabular}{c|c|c|c|} 
& S10 & S12 & SX \\
\hline S10 & 0.998 & 0.001 & 0.001 \\
\hline S12 & 0.001 & 0.998 & 0.001 \\
\hline SX & 0.001 & 0.001 & 0.998 \\
\hline
\end{tabular}

Tabela 13: $\operatorname{Pr}($ c.mg.mutation $\mid$ c.omg) e $\operatorname{Pr}($ c.pg.mutation $\mid$ c.opg $)$ O alelo passado pelo genitor - opg ou omg - cujos valores possíveis são apresentados na primeira linha da tabela, pode sofrer mutação. O alelo após considerar a possibilidade de mutação - cujos valores possíveis são apresentados na primeira coluna da tabela - vai compor o genótipo do filho.

A taxa de mutação de uma alelo para outro é o valor apresentado na intesecção de coluna e linha. 


\begin{tabular}{c|c|c|c|c|c|c|c|c|c|} 
c.pg.mutation & \multicolumn{3}{|c|}{ S10 } & \multicolumn{3}{c|}{ S12 } & \multicolumn{3}{c|}{ SX } \\
c.mg.mutation & S10 & S12 & SX & S10 & S12 & SX & S10 & S12 & SX \\
\hline S10.S10 & 1 & 0 & 0 & 0 & 0 & 0 & 0 & 0 & 0 \\
\hline S10.S12 & 0 & 1 & 0 & 1 & 0 & 0 & 0 & 0 & 0 \\
\hline S10.SX & 0 & 0 & 1 & 0 & 0 & 0 & 1 & 0 & 0 \\
\hline S12.S12 & 0 & 0 & 0 & 0 & 1 & 0 & 0 & 0 & 0 \\
\hline S12.SX & 0 & 0 & 0 & 0 & 0 & 1 & 0 & 1 & 0 \\
\hline SX.SX & 0 & 0 & 0 & 0 & 0 & 0 & 0 & 0 & 1 \\
\hline
\end{tabular}

Tabela 14: $\operatorname{Pr}($ c.gt|c.pg.mutation, c.mg.mutation $)$

Após considerar a possibilidade de mutação, o genótipo do filho - cujos valores possíveis estão na primeira coluna da tabela - é determinístico e dado pela combinação dos alelos recebidos - listados nas duas primeiras linhas da tabela. Por exemplo, na primeira coluna o alelo recebido do pai é S10 e o recebido da mãe é S10, o genótipo resultante é S10.S10. Na segunda coluna o alelo recebido do pai é S10 e o da mãe é S12, o genótipo resultante é S10.S12. 


\begin{tabular}{c|c|c|c|c|c|c|c|c|c|c|c|c|} 
f.gt & \multicolumn{2}{|c|}{ S10.S10 } & \multicolumn{2}{c|}{ S10.S12 } & \multicolumn{2}{c|}{ S10.SX } & \multicolumn{2}{c|}{ S12.S12 } & \multicolumn{2}{c|}{ S12.SX } & \multicolumn{2}{c|}{ SX.SX } \\
Test.f.is.father & yes & no & yes & no & yes & no & yes & no & yes & no & yes & no \\
\hline S10.S10 & 1 & 0.1 & 0 & 0.1 & 0 & 0.1 & 0 & 0.1 & 0 & 0.1 & 0 & 0.1 \\
\hline S10.S12 & 0 & 0.2 & 1 & 0.2 & 0 & 0.2 & 0 & 0.2 & 0 & 0.2 & 0 & 0.2 \\
\hline S10.SX & 0 & 0.3 & 0 & 0.3 & 1 & 0.3 & 0 & 0.3 & 0 & 0.3 & 0 & 0.3 \\
\hline S12.S12 & 0 & 0.05 & 0 & 0.05 & 0 & 0.05 & 1 & 0.05 & 0 & 0.05 & 0 & 0.05 \\
\hline S12.SX & 0 & 0.15 & 0 & 0.15 & 0 & 0.15 & 0 & 0.15 & 1 & 0.15 & 0 & 0.15 \\
\hline SX.SX & 0 & 0.2 & 0 & 0.2 & 0 & 0.2 & 0 & 0.2 & 0 & 0.2 & 1 & 0.2 \\
\hline
\end{tabular}

Tabela 15: $\operatorname{Pr}($ c.father.gt|f.gt,Test.f.is.father $)$

O teste de paternidade consiste em comparar as probabilidades dos possíveis genótipos do pai ("verdadeiro") inferidos a partir da genealogia com as de um indivíduo qualquer da população que presume-se seja o pai, cujo genótipo foi medido. Caso o pai presumido seja o pai verdadeiro, seus

genótipos têm que ser iguais, caso o pai presumido não seja o pai verdadeiro, a probabilidade de ocorrência de um certo genótipo é a probabilidade de ocorrência desse genótipo na população. Na tabela, a primeira linha apresenta os possíveis genótipos do pai presumido, a segunda linha apresenta os valores da variável de decisão e representa yes sim, pai presumido é o pai verdadeiro, ou no, pai presumido não é o pai verdadeiro.

Os possíveis genótipos do pai verdadeiro são apresentados na primeira coluna da tabela.

\begin{tabular}{c|c|} 
& $\operatorname{Pr}($ Test.f.is.father $)$ \\
\hline yes & 0.5 \\
\hline no & 0.5 \\
\hline
\end{tabular}

Tabela 16: $\operatorname{Pr}$ (Test.f.is.father)

Esta é a variável de decisão. Em princípio como nenhuma informação foi fornecida, assume-se que a probabilidade do indivíduo ser pai é igual a dele não ser pai, ou seja, 0.5. 
Existem casos em que se deseja testar tanto o vínculo de paternidade quanto o de maternidade. Isto pode ocorrer quando ambos os genitores falecem e neste caso genótipos de avós, tios e irmãos reconhecidos do demandante são usados para o cálculo, resultando em um heredograma extenso.

A seguir será apresentado o modelo de referência. 


\subsection{Modelo de Referência}

O modelo de referência para este trabalho é o modelo de Dawid e Mortera [Dawid, 2000] onde o componente básico é um alelo de um indivíduo, no sentido que um indivíduo é representado por dois alelos, um materno, representado por $m g$ e um paterno, representado por $p g$ a combinação dos dois através de um nó determinístico - cuja função de probabilidade é apresentada na tabela 17 - resulta no genótipo gt e permite a introdução da evidência no genótipo de tal indivíduo, como ilustrado na figura 18.

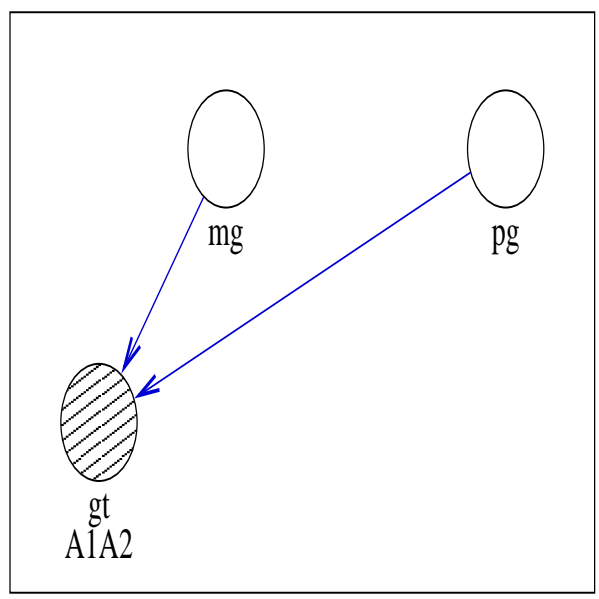

Figura 18: Representação do Indivíduo.

\begin{tabular}{c|c|c|c|c|} 
mg & \multicolumn{2}{|c|}{ A1 } & \multicolumn{2}{c|}{ A2 } \\
pg & A1 & A2 & A1 & A2 \\
\hline A1A1 & 1 & 0 & 0 & 0 \\
\hline A1A2 & 0 & 1 & 1 & 0 \\
\hline A2A2 & 0 & 0 & 0 & 1 \\
\hline
\end{tabular}

Tabela 17: p(gt | mg, pg) - Genótipo do Indivíduo.

Sabe-se que este indivíduo pertence à população mas não há informação a respeito de seus ascendentes, portanto a informação disponível é a freqüência dos alelos na população (tabela 18). Com esta combinação de informações - freqüências alélicas e genótipo dado por uma regra determinística - as freqüências genotípicas por construção obedecem ao equilíbrio de HardyWeinberg. 


\begin{tabular}{c|c|} 
& $\mathrm{p}(\mathrm{pg})$ \\
\hline $\mathrm{A} 1$ & 0.3 \\
\hline $\mathrm{A} 2$ & 0.7 \\
\hline
\end{tabular}

Tabela 18: $\operatorname{Pr}(\mathrm{pg})$ - Freqüências dos alelos na população.

A passagem do alelo do genitor para seu descendente é modelada da mesma maneira que no modelo proposto. O gene original, cgo, no sentido que ainda não sofreu mutação pode ser qualquer um dos alelos do genitor. O alelo pode sofrer uma mutação mut, gerando o gene que está presente no descendente. A representação do indivíduo acrescida da passagem de alelo para o descendente é apresentada na figura 19.

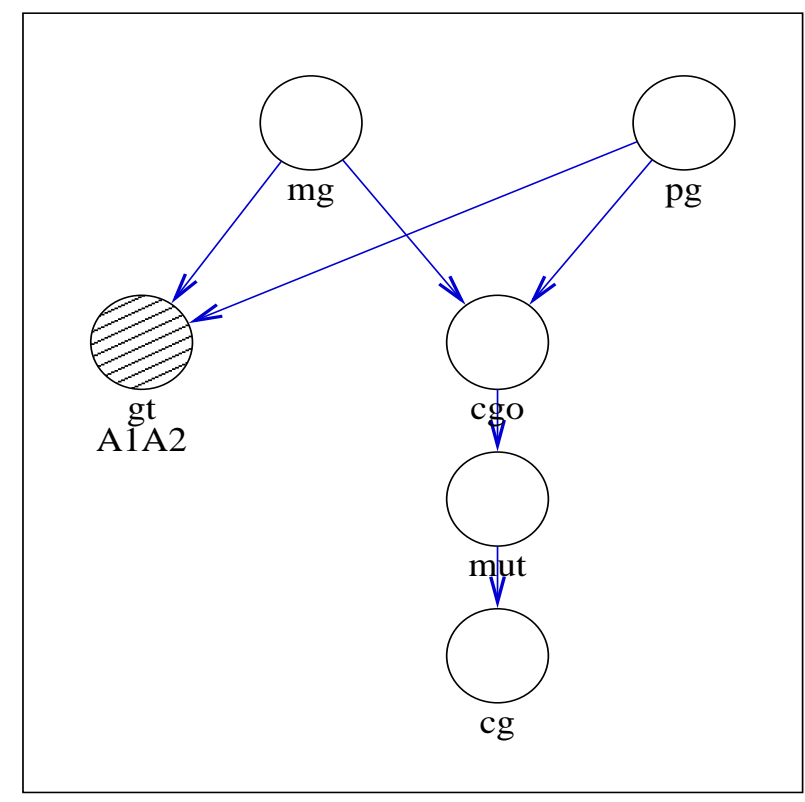

Figura 19: Representação de um indivíduo no modelo DM.

Com este modelo de indivíduo, e relação de paternidade é possível descrever qualquer pedigree, por exemplo, o de um trio, apresentado na figura 20 onde as representações dos indivíduos estão destacadas por elipses. 


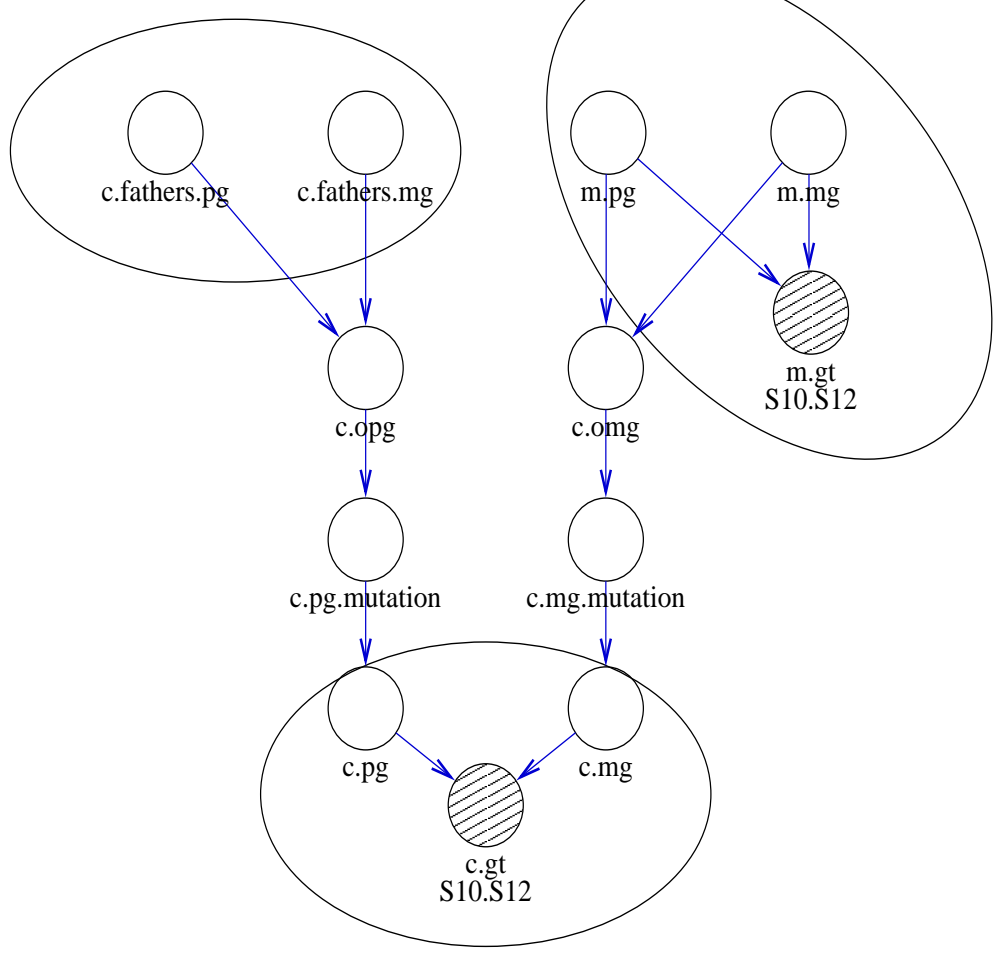

Figura 20: Rede Bayesiana para um Trio 


\subsection{Relação entre o modelo proposto e o de referência}

É possível partir do modelo de referência e chegar ao modelo proposto agrupando os nós que representam um indivíduo no modelo de referência em um só nó. O inverso é possível desde que as freqüências genotípicas e as freqüências alélicas populacionais se relacionem conforme descrito na seção que explica o equilíbrio de Hardy-Weinberg. Neste sentido o modelo proposto é mais geral que o modelo de referência.

Em [Barlow,1998 ], no capítulo 9 é apresentado o formalismo de diagramas de influência, que a menos de convenções gráficas tem a mesma definição de redes bayesianas. Nesse formalismo incluem-se operações de fusão e separação de nós.

Lembrando que nós determinísticos podem ser adicionados ou removidos sem alterar a distribuição de probabilidade que a rede bayesiana representa, no modelo de referência todos os nós que representam os genótipos podem estar colocados. Dois nós de uma rede bayesiana podem ser fundidos se houver uma aresta entre eles e desde que dessa fusão não resulte ciclo.Logo pode-se fundir o nó que representa o genótipo aos nós que representam os alelos materno e paterno. O modelo resultante é o modelo proposto.

Para indivíduos cuja única informação é de que eles pertencem a uma população com certa freqüência alélica, o nó resultante da fusão apresenta freqüências genotípicas que obedecem ao equilíbrio de Hardy-Weinberg por construção. Isto mostra que, por usar frequiências alélicas, o modelo de referência fica restrito a um conjunto restrito de freqüências genotípicas, enquanto o modelo proposto tem isso livre.

Desta forma o modelo proposto é mais flexível, pois permite o uso de frequiências genotípicas que obedeçam ou não ao equilíbrio de Hardy-Weinberg.

\subsection{Exemplo onde há diferença entre o modelo pro- posto e o modelo de referência}

A fim de exemplificar a diferença entre o modelo proposto e o modelo de referência verifica-se o que ocorre com a probabilidade de paternidade fora do equilíbrio. Para tal, serão testados seis casos (DW1 DW6) de um locus com dois alelos e três genótipos com as contagens de indivíduos por genótipo dadas na tabela 19. Em todos os casos há mil indivíduos, logo as freqüências genotípicas são as apresentadas na tabela 20. As freqüências alélicas são obtidas por contagem, em todos os casos são de $0.5\left(f_{S 10}=f_{S X}=0.5\right)$. A 
situação em que há equilíbrio é DW4 e está assinalada com (*).

\begin{tabular}{c|c|c|c|c|c|c} 
& DW1 & DW2 & DW3 & DW4* & DW5 & DW6 \\
\hline S10_S10 & 10 & 50 & 150 & 250 & 350 & 450 \\
S10_SX & 980 & 900 & 700 & 500 & 300 & 100 \\
SX_SX & 10 & 50 & 150 & 250 & 350 & 450
\end{tabular}

Tabela 19: Contagem de indivíduos por genótipo

\begin{tabular}{c|c|c|c|c|c|c} 
& DW1 & DW2 & DW3 & DW4* & DW5 & DW6 \\
\hline S10_S10 & 0.01 & 0.05 & 0.15 & 0.25 & 0.35 & 0.45 \\
S10_SX & 0.98 & 0.9 & 0.7 & 0.5 & 0.3 & 0.1 \\
SX_SX & 0.01 & 0.05 & 0.15 & 0.25 & 0.35 & 0.45
\end{tabular}

Tabela 20: Freqüências genotípicas

A família a estudar é ilustrada na figura 21, tem dois demandantes, c1 e c2 com genótipos S10_SX e S10_S10 respectivamente. O demandado tem genótipo S10_SX e a mãe tem genótipo S10_S10. No modelo de referência, que usa freqüências alélicas, em todos os casos a probabilidade de paternidade é 0.667 . No modelo proposto a probabilidade varia de 0.505 a 0.909 conforme a tabela 21. Essa variação se deve a freqüência do genótipo do demandado (S10_SX) - quanto mais raro o genótipo na população maior a probabilidade do demandado ser pai.

\begin{tabular}{c|c|c|c|c|c|c} 
& DW1 & DW2 & DW3 & DW4* & DW5 & DW6 \\
\hline$f_{\text {S10_SX }}$ & 0.98 & 0.9 & 0.7 & 0.5 & 0.3 & 0.1 \\
$\operatorname{Pr}($ f ser o pai $)$ & 0.505 & 0.526 & 0.588 & 0.667 & 0.769 & 0.909
\end{tabular}

Tabela 21: Probabilidade de paternidade obtida usando o modelo proposto

Neste exemplo, pelo perfil de DNA da mãe e dos demandantes, o pai biológico (ou "pai verdadeiro") certamente tem o genótipo S10_SX pois a mãe só pode passar aos filhos o alelo S10, logo, o pai biológico passou para um dos filhos o alelo S10 e para o outro o SX. A rede bayesiana pode ser simplificada aos nós relativos ao teste de hipótese mostrado no capítulo anterior e ilustrado na figura 22.

Tanto intuitiva quanto formalmente, mostrou-se que quanto mais raro é o genótipo, maior a probabilidade de que o demandado seja o pai biológico, en- 


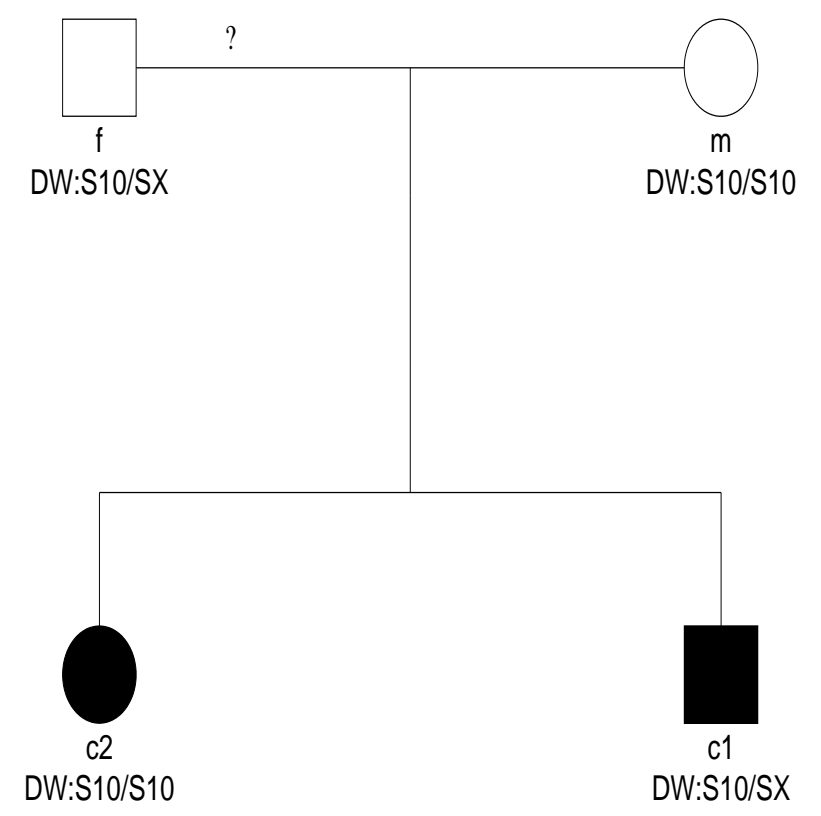

Figura 21: Comparação entre modelos - Família a estudar.

tretanto no modelo de referência, que requer que o locus esteja em equilíbrio, esta propriedade não é utilizada. 


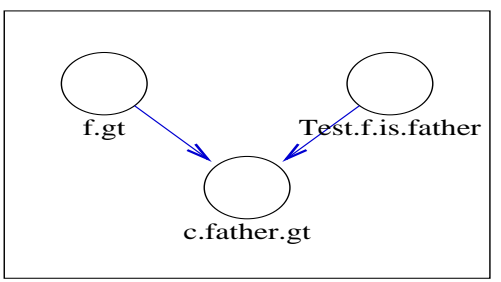

Figura 22: Teste da hipótese do demandado ser o pai biológico 


\section{Referências}

[Barlow,1998 ]

[Dawid, 2000]
BARLOW, RICHARD E. - Engineering Reliability - 1988, ASA-SIAM

DAWID, MORTERA, PASCALI, VAN BOXEL Probabilistic Expert Systems for Forensic Inference from Genetic Markers

2000 - Department of Statistical Science, University College London 


\section{Implementação}

Neste ponto usuários de ambientes de cálculo de redes bayesianas que tenham interesse em cálculo de probabilidade de paternidade devem ser capazes de especificar redes que realizam os cálculos. Mesmo para este público especializado, haveria dificuldades consideráveis de operação. Pois uma rede para cada família e para cada locus precisa ser especificada. Na especificação da rede, cada nó tem associada uma tabela de probabilidades, cuja quantidade de elementos (probabilidades) aumenta de maneira linear ou quadrática em função do número de alelos, o que faz do processo de tradução manual de um heredograma em rede bayesiana uma tarefa demorada e muito sujeita a erros. Logo, é desejável um software que receba como entrada uma especificação do problema na linguagem mais simples possível e que automaticamente gere as redes bayesianas, faça os cálculos e gere o relatório com todos os resultados.

Segundo [Aho,1986], um compilador é um programa que lê um arquivo escrito em uma linguagem (linguagem-fonte) e o converte em um arquivo equivalente noutra linguagem (linguagem-alvo). Neste procedimento construções complexas e particularidades da linguagem-alvo se tornam transparentes ao usuário. Por exemplo, o teste de um locus para um trio pode ser definido em dez linhas curtas com uma única tabela. A rede bayesiana correspondente tem nove variáveis aleatórias e o mesmo número de tabelas de probabilidade.

Alguém poderia perguntar se desenvolver uma interface gráfica em um gerenciador de janelas, ou uma interface Web substituiria o compilador com vantagens. Este tipo de desenvolvimento requer pessoal especializado - programadores, webdesigners - em geral com experiência em programação mas sem conhecimento em exames genéticos ou em redes bayesianas. Tanto para o especialista do laboratório de exames genéticos quanto para os desenvolvedores de interfaces de computador, é conveniente abstrair os detalhes do modelo e das ferramentas de modelagem matemática utilizadas. Um compilador volta a ser necessário.

Optou-se por desenvolver vários módulos com tarefas restritas e bem definidas a desenvolver um único programa que executa todas as tarefas. Esta arquitetura de sistemas provê tanto flexibilidade quanto facilidade na localização de erros. O fluxo de funcionamento dos programas é ilustrado na figura 23. O usuário escreve o arquivo de especificação, na linguagem de descrição de marcadores e heredogramas. Este arquivo pode ser submetido ao compilador de heredogramas pater ou ao documentador paterdoc.

O compilador pater gera as redes bayesianas - uma para cada locus e 


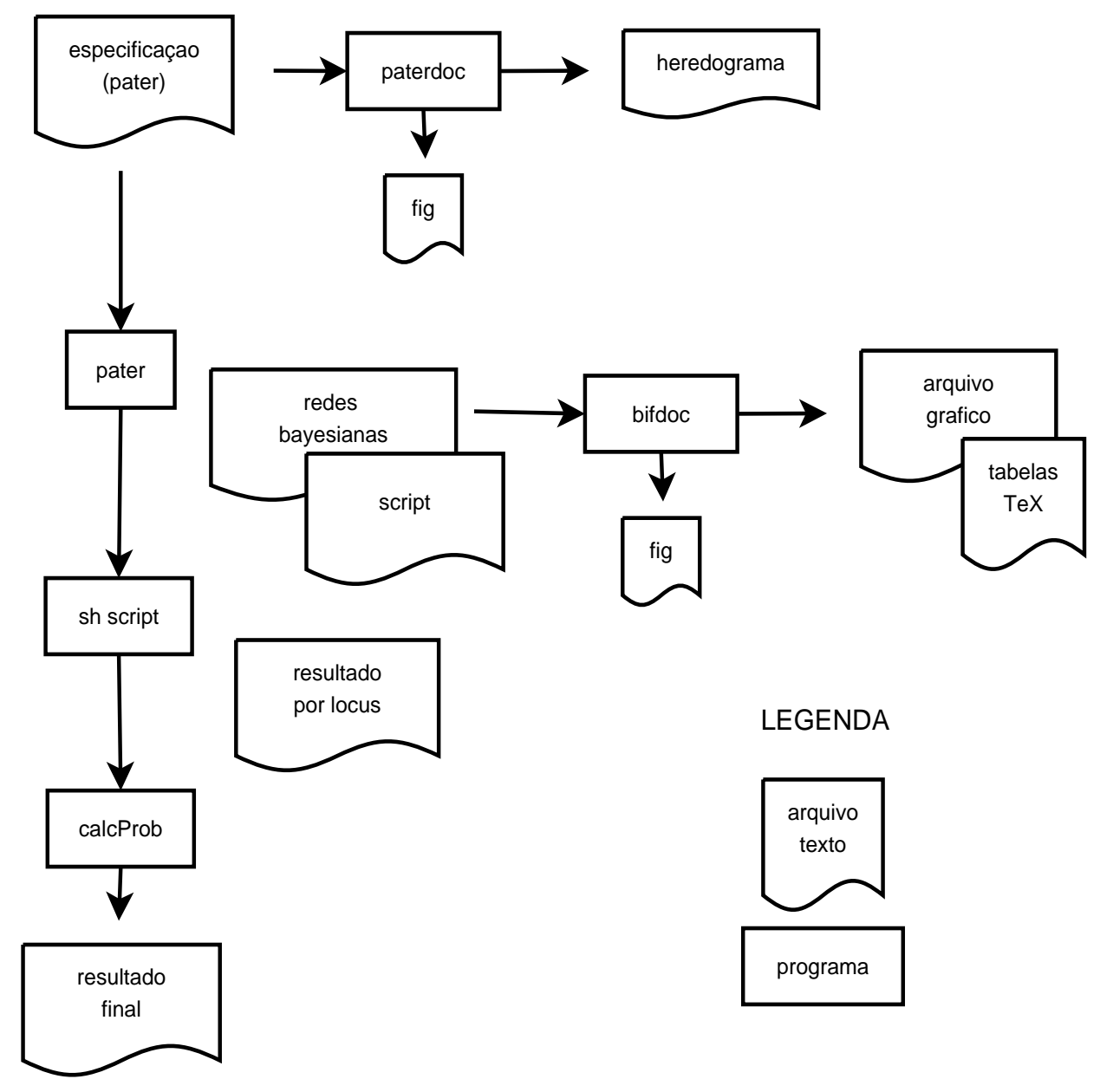

Figura 23: Fluxo de funcionamento

um script. Há duas versões do compilador, uma gera as redes conforme o modelo de referência, outra, conforme o modelo proposto. Gráficos e tabelas que descrevem as redes bayesianas são gerados com o bifdoc. O cálculo das probabilidades de paternidade por locus é feito executando o script com o comando sh script.

calcProb combina as probabilidades por locus em uma probabilidade de paternidade considerando todos os loci. Detalhes sobre o uso dos programas são fornecidos na respectiva subseção.

Cada um dos programas tem uma subseção própria neste capítulo. A maioria desses programas depende da linguagem que especifica heredogramas 
e marcadores, definida na próxima subseção.

\subsection{Definição da Linguagem}

A definição cuidadosa da linguagem é parte importante do projeto pois é a maneira como o usuário se comunica com a ferramenta. Uma linguagem sintética, flexível e que evita erros facilita o uso e aceitação da ferramenta.

Neste projeto optou-se por desenvolver uma linguagem com elementos sintáticos de linguagens orientadas a objeto, que resultaram em construções sucintas e precisas.

Objetos são representações genéricas, por exemplo, indivíduos, sem referência a um específico. Um indivíduo específico, por exemplo, Jose, é uma instância do objeto, e tem certos atributos, como seu genótipo, e sobre ele podem ser aplicados métodos, como atribuir paternidade. Também é objeto um marcador, marcadores específicos são, por exemplo, TPOX, FGA, VWA, que têm como atributos os alelos possíveis, as freqüências alélicas, genotípicas e as taxas de mutação. Um exemplo prático é apresentado abaixo, nele é analisado um trio em que são conhecidos os genótipos do pai presumido, da mãe e do filho para o marcador (fictício) DW. Os números das linhas foram acrescentados para facilitar a leitura, de fato, no arquivo, caso as linhas sejam numeradas ocorre erro.

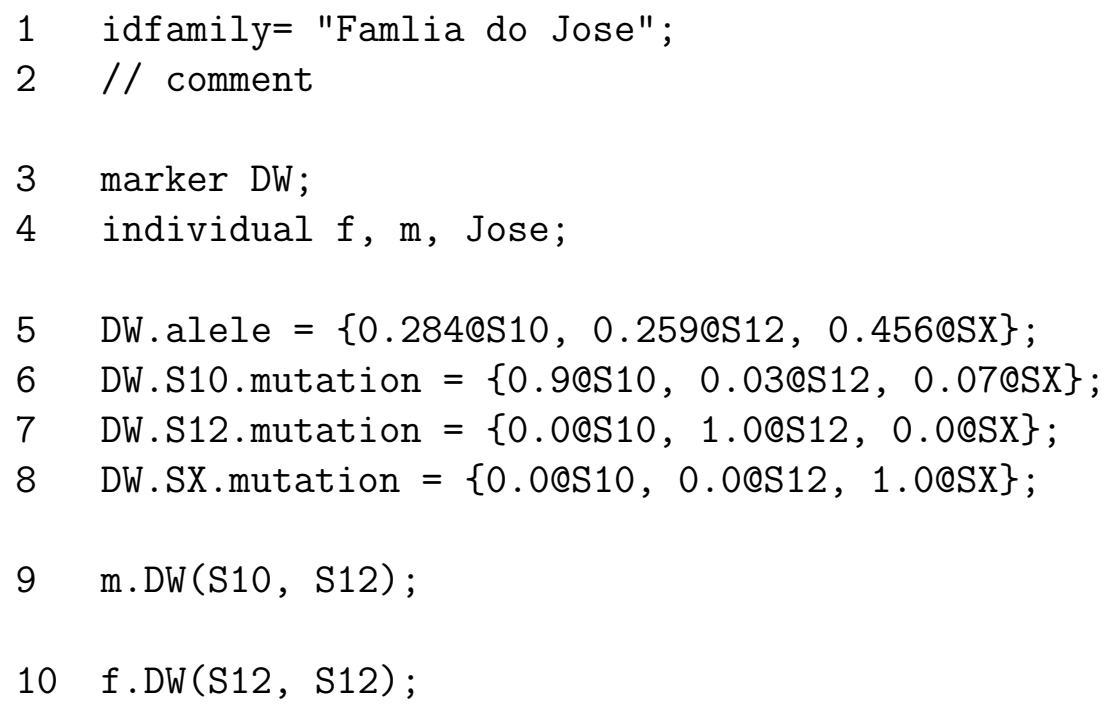


11 Jose.parents $(f, m)$;

12 Jose.DW(S10, S12);

13 Jose.claimfather;

A linha 1 apresenta a identificação da família utilizando a palavra reservada "idfamily". A linha 2 apresenta a sintaxe de um comentário - após as duas barras tudo o que for escrito é ignorado pelo compilador. Na linha 3 a variável DW é declarada como um marcador. Todos os marcadores precisam ser declarados, caso isso não seja feito, o compilador gera um erro indicando a linha em que o marcador não declarado foi utilizado. Os nomes dos marcadores são de livre escolha, desde que sejam nomes, ou seja, comecem por uma letra e não contenham símbolos como pontos ou vírgulas, não há marcadores com nomes pré-estabelecidos. Na linha 4 são declarados os indivíduos utilizados no heredograma, não há indivíduos especiais, ou seja, não há obrigação de que o pai presumido seja notado como $f$, por exemplo. É importante que os indivíduos que conectam aqueles que foram examinados também sejam declarados, por exemplo, caso o pai presumido não tenha sido examinado, mas sim seu irmão, a conexão entre o pai e seu irmão se dá através dos avós, assim, eles precisam ser declarados e fazer parte do heredograma. Na linha 5 , os alelos do marcador DW e a freqüência de cada um dos alelos são declarados. Um marcador tem atributos, nominalmente, lista de alelos, freqüências alélicas, genotípicas e taxas de mutação. Os dois primeiros são dados simultanemante, por meio do atributo "aleles". Os alelos de DW são S10, S12 e Sx com freqüências 0.284 em S10, 0.259 em S12 e 0.456 em Sx. As linhas 6,7,8 definem as taxas de mutação para cada alelo. Na linha 6 , a taxa de mutação do alelo S10 para o alelo S10 é 0.9 (este elemento representa a conservação do alelo), de S10 para S12 é 0.03 e de S10 para Sx é 0.07. A linha 9 define o genótipo do indivíduo m para marcador DW como S10,S12.A linha 10 faz o mesmo para o indivíduo f, marcador DW com genótipo S12,S12. A linha 11 descreve a única relação de parentesco, informando que os genitores de Jose são f e m. Neste método são passados dois indivíduos, assume-se que o primeiro seja o pai e o segundo seja a mãe, alternativamente, pode se usar "Jose.father(f); Jose.mother(m);". A linha 12 define o genótipo de Jose, e a linha 13 informa que Jose reclama que fé seu pai. Caso fosse um problema de definição de maternidade, utilizar-se-ia o método "claimmother". Para definir um teste conjunto de paternidade e maternidade, ambos "claimfather" e "claimmother" precisam ser informados. 
Segue a lista completa de palavras reservadas da linguagem. Estas palavras têm função especial e portanto não podem ser usadas como nomes de indivíduos, marcadores ou alelos. Por diminuir a clareza do texto, embora válido, não é recomendável utilizar prefixos ou sufixos

- IdFamily - Identificador da família descrita no arquivo

- marker - Marcadores utilizados

- aleles - alelos de cada marcador e sua freqüência

- mutation - taxa de mutação entre os alelos

- individual - indivíduos no heredograma

- parents - indica relação de paternidade entre indivíduos

- father - indica relação de paternidade entre indivíduos

- mother - indica relação de paternidade entre indivíduos

- sex - indica o sexo do indivíduo que pode ser "male" ou "female"

- claimfather, claimmother - indica que o indivíduo é reclamante e se reclama pela paternidade, maternidade ou ambos.

- equilibrium - no modelo que utiliza freqüências genotípicas, converte freqüências alélicas em freqüências genotípicas considerando apenas herança mendeliana. No modelo que utiliza freqüências alélicas, converte freqüências genotípicas em freqüências alélicas por contagem de alelos.

- with, do, end - não implementado - permite construções em que há elipse do objeto que está sendo modificado.

Além das palavras reservadas, há também símbolos reservados, são símbolos que têm função especial e portanto não podem fazer parte de nomes.

- arroba @ - associa valor a variáveis em vetores associativos por exemplo, $0.25 @ S 12$ na definição de um alelo significa que a freqüência populacional do alelo $S 12$ é 0.25 . 
- chaves \{\} - delimita vetores associativos. A seqüência de alelos e suas freqüências na definição de um marcador é um vetor associativo, como na linha 5 do exemplo.

- colchetes [ ] - reservado para uso futuro

- parentesis ( ) - delimita argumentos para objetos ou métodos

- vírgula, - separa elementos dentro de vetores associativos

- ponto . - operador de indireção. O operador de indireção permite o acesso a atributos e métodos dos objetos, por exemplo, DW.alele acessa o atributo alele do objeto $D W$, permitindo que os valores - lista de alelos e freqüências sejam modificados.

- ponto e vírgula ; - separador de sentenças.

- sinal de igual = - operador de atribuição.

- aspas " " - delimitador de seqüêcias de caracteres.

- barra dupla // - sinalizador de comentário. Após a barra dupla, todos os caracteres que se seguem na linha são ignorados.

\subsubsection{Definições Léxicas e Sintáticas}

Com o objetivo de apresentar uma descrição completa e concisa da linguagem, são apresentados a seguir as definições dos elementos léxicos e expressões na linguagem dos aplicativos utilizados para desenvolver o compilador.

Abaixo definimos os elementos léxicos da linguagem:

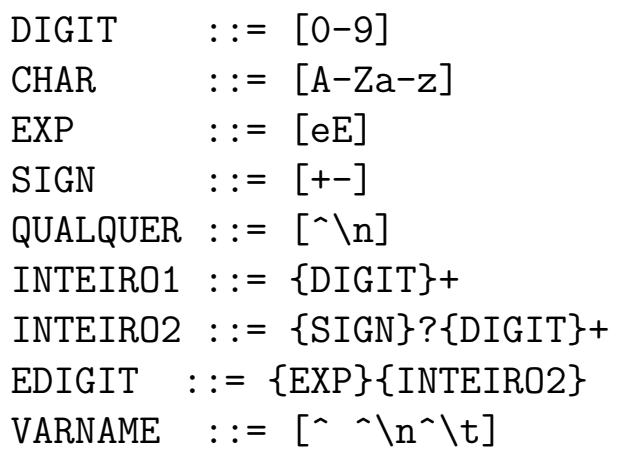




$$
\begin{aligned}
& \text { " //" \{QUALQUER }\} * \\
& \text { /* Tokens */ } \\
& \text { Y_IDFAMILY }::=\text { "idfamily" } \\
& \text { Y_MARKER }::=\text { "marker" } \\
& \text { Y_ALELE } \quad::=\text { "alele" } \\
& \text { Y_MUTATION }::=\text { "mutation" } \\
& \text { Y_INDIVIDUAL }::=\text { "individual" } \\
& \text { Y_PARENTS } \quad::=\text { "parents" } \\
& \text { Y_FATHER }::=\text { "father" } \\
& \text { Y_MOTHER }::=\text { "mother" } \\
& \text { Y_GENOTYPE }::=\text { "genotype" } \\
& \text { Y_SEX }::=\text { "sex" } \\
& \text { Y_CLAIM } \quad::=\text { "claim" } \\
& \text { Y_CLAIMFAHER }::=\text { "claimfather" } \\
& \text { Y_CLAIMMOTHER }::=\text { "claimmother" } \\
& \text { Y_WITH }::=\text { "with" } \\
& \text { Y_DO }::=\text { "do" } \\
& \text { Y_END } \quad::=\text { "end" } \\
& \text { Y_EQUILIBRIUM }::=\text { "equilibrium" } \\
& \text { Y_SEX } \quad::=\text { "sex" } \\
& \text { Y_MALE } \quad::=\text { "male" } \\
& \text { Y_FEMALE }::=\text { "female" } \\
& \text { /* Remove comentarios. */ } \\
& \text { /* Identificadores } * / \\
& \text { Y_IDENT } \quad::=\{\mathrm{CHAR}\}(\{\mathrm{CHAR}\} \mid\{\mathrm{DIGIT}\}) * \\
& \text { Y_ID_MARKER }::=\{\mathrm{CHAR}\}(\{\mathrm{CHAR}\} \mid\{\mathrm{DIGIT}\}) * \\
& \text { Y_ID_ALELE }::=\{\mathrm{CHAR}\}(\{\mathrm{CHAR}\} \mid\{\mathrm{DIGIT}\}) * \\
& \text { Y_ID_INDIV }::=\{\mathrm{CHAR}\}(\{\mathrm{CHAR}\} \mid\{\mathrm{DIGIT}\}) * \\
& \text { /* Numeros */ } \\
& \text { Y_FLOAT }::=\{\text { INTEIRO } 1\} " . "\{\text { DIGIT }\}+\{\text { EDIGIT }\} ? \\
& \text { Y_INT } \quad::=\{\text { INTEIRO1 }\}
\end{aligned}
$$

Segue a definição da sintaxe da linguagem: 


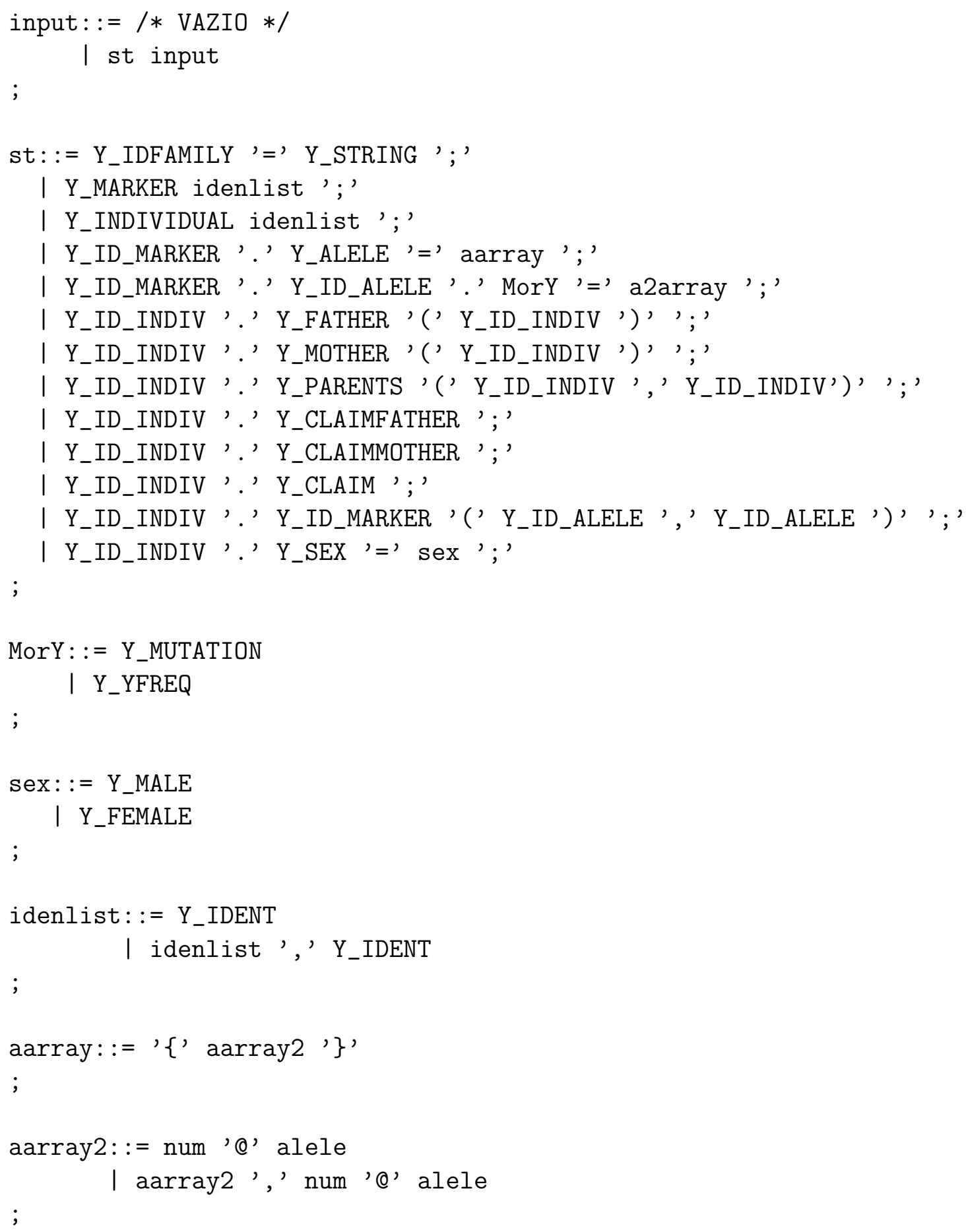




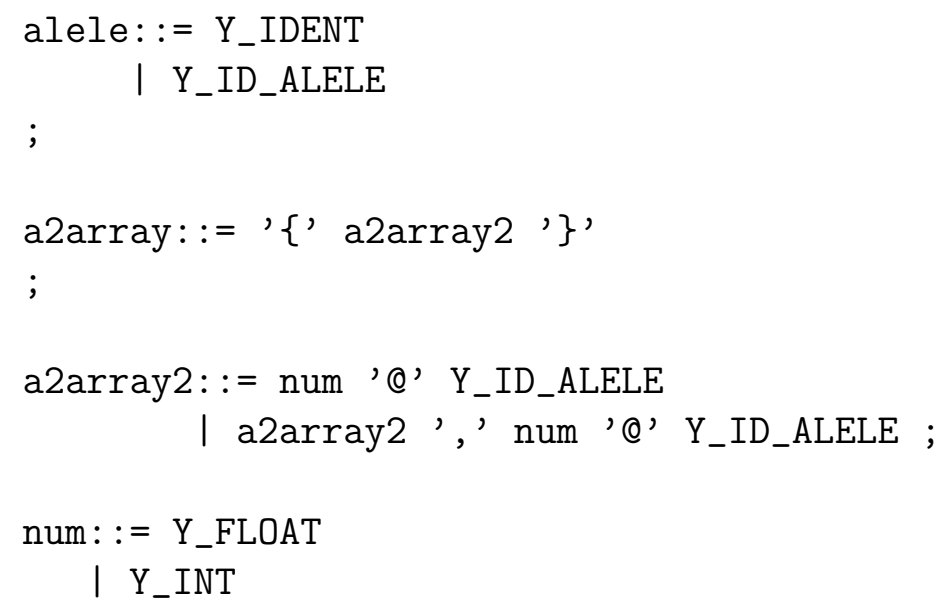

\section{2 pater}

O "compilador de heredogramas" - pater - é um software que lê arquivos escritos na linguagem definida na seção anterior e constrói as Redes Bayesianas que descrevem o problema. Tanto o modelo de referência quanto o modelo proposto foram implementados e ambas as implementações podem gerar arquivos na linguagem BIF - para carga no JavaBayes - ou arquivos JAVA para compilação e uso no EmBayes.

JavaBayes é um ambiente gráfico para edição e inferência em redes bayesianas. Por permitir a visualização gráfica e edição interativa das redes geradas pelo compilador, é ferramenta útil para a localização de erros no compilador. Entretanto não permite que inferências (cálculos de probabilidade de paternidade) sejam feitas sem intervenção de um usuário, o que impossibilita automação. Para que inferências sejam feitas sem intervenção usa-se o EmBayes. Com isso há quatro versões do compilador em que se escolhe combinações de modelo (freqüência genotípica ou alélica) e de linguagem-alvo (BIF ou JAVA).

Em linhas gerais, todas as quatro variações do compilador têm uma fase em que o arquivo-fonte é lido e a tabela de símbolos é preenchida e outra fase em que a tabela de símbolos é lida, às vezes mais de uma vez, e os arquivos-alvo são gerados.

A tabela de símbolos é uma lista ligada constituída por registros desenhados para agilizar a construção das redes bayesianas e dos heredogramas. 
Registros são criados na medida do necessário e armazenam um número ou ponteiros para dados de um indivíduo, marcador ou alelo, que correspondem às variáveis do teste de paternidade. Segue abaixo a definição de um registro.

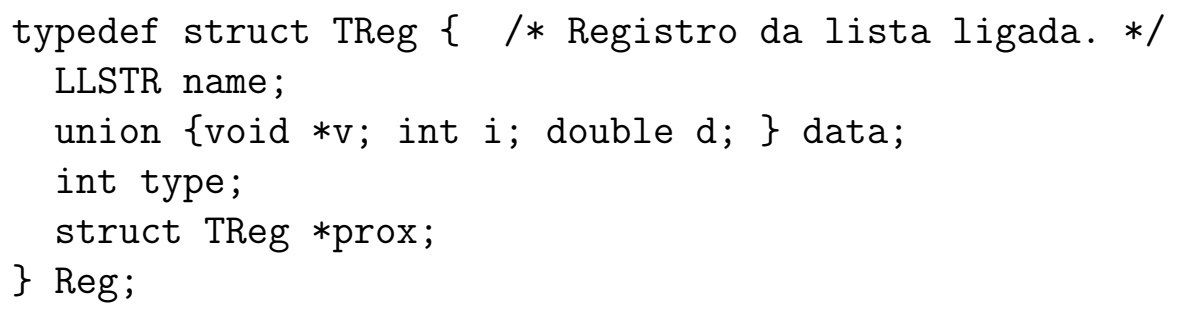

Nos registros, os campos "name" e "type" são sempre preenchidos - o tipo é codificado como o número atribuído ao respectivo token, por exemplo, no tipo "alelo" o campo "type" vale Y_ID_ALELE.

O tipo "alelo" tem apenas seu nome registrado, a estrutura "data" permanece vazia. Nos tipos "indivíduos" e "marcadores", o campo "data" é um ponteiro para as estruturas "Individual" ou "Marker" listadas abaixo.

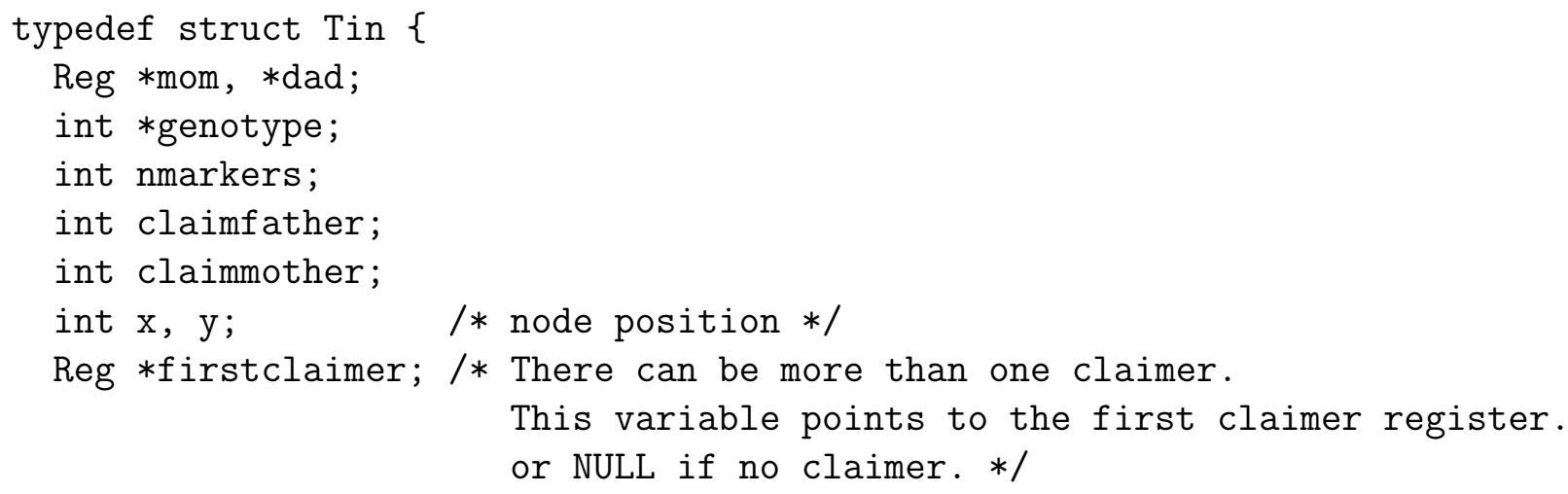

A estrutura "Marker" contém um identificador seqüencial do marcador (idx), a lista dos nomes dos alelos desse marcador, o vetor de freqüências populacionais dos alelos e a matriz com a taxa de mutação entre os alelos. 
A estrutura "individual" consiste em um ponteiro para o pai do indivíduo e um ponteiro para a mãe, um vetor de duplas em que cada posição corresponde a um marcador (indexado pelo campo idx), dois flags indicando se o indivíduo reclama pela paternidade ou maternidade, e caso ele seja demandado, um ponteiro para o registro do primeiro demandante.

A cada marcador, indivíduo ou alelo novo encontrado no arquivo-fonte, um registro é criado e a cada linha lida a informação contida na linha, por exemplo taxa de mutação, é armazenada na tabela de símbolos. Esta é percorrida várias vezes, em cada uma das passagens uma seção do arquivoalvo é criado.

Quando o arquivo-alvo é processado pelo JavaBayes, a linguagem-alvo é BIF (Binary Interchange Format). Para gerar esse formato, a tabela de símbolos é percorrida duas vezes. Na primeira os nós da rede bayesiana são declarados e na segunda as tabelas de probabilidade são declaradas. Nenhum arquivo auxiliar é escrito.

Quando o arquivo-alvo é processado pelo EmBayes, a linguagem-alvo é JAVA. Para gerar esse formato, a tabela de símbolos é percorrida seis vezes para declarar as variáveis, declarar as tabelas de probabilidade, inicializar as variáveis, inicializar as tabelas de probabilidade, transferir para o EmBayes as variáveis e finalmente transferir para o EmBayes as tabelas de probabilidade. É gerado um arquivo auxiliar contendo a seqüência de comandos para o EmBayes, e a cada teste (de vários loci) é gerado um script, ou arquivo batch que quando executado chama o EmBayes e agrupa as probabilidade de paternidade por locus em um único arquivo.

A chamada do compilador, independente da linguagem-alvo, é:

pater <pater input file> <output shell script file>

Os arquivos de saída, contendo uma rede bayesiana por locus recebe o nome "<pater input file $><$ locus $>$.bif" quando a linguagem-alvo é BIF. Quando é JAVA todos os pontos são substituídos por underlines e o arquivo recebe a extenso ".java". Também um scripte um arquivo auxiliar são gerados.

\section{3 sh script}

scripts ou arquivos batch contém comandos do sistema operacional (LINUX ou Windows) que podem, entre outras coisas, executar programas, criar e apagar arquivos. Em LINUX, um script é executado por: 
sh <script>

O script gerado pelo compilador de heredogramas executa o EmBayes para todas as redes bayesianas e concatena o resultado (probabilidade) por locus em um único arquivo texto. Segue abaixo um exemplo de script gerado pelo compilador.

rm cmdres.txt

javac pater_DW6.java pater_DW5.java pater_DW4.java pater_DW3.java pater_DW2.java pa java embayes.EmBayes <DIFERENTE >>cmdres.txt

Este script apaga o arquivo cmdres.txt, caso ele exista, compila as seis redes bayesianas, gerando as respectivas classes que deverão ser carregadas no EmBayes e chama o EmBayes. A entrada do EmBayes é redirecionada para o arquivo auxiliar e saída para o arquivo cmdres.txt, que acumula os resultados.

O arquivo auxiliar contém os comando do Embayes para carga de cada rede bayesiana (comando "l < classe $>$ ") e inferência da probabilidade de paternidade (comando "i Test_f_is_fahther"), como exemplificado abaixo.

1 pater_DW6

$i$ Test_f_is_father

1 pater_DW5

$i$ Test_f_is_father

1 pater_DW4

i Test_f_is_father

1 pater_DW3

i Test_f_is_father

1 pater_DW2

i Test_f_is_father

1 pater_DW1

i Test_f_is_father

q

O arquivo de resultado contém todas as mensagens e resultados gerados pelo EmBayes. O nome do locus é apresentado na linha "Loaded Class" e o valor da probabilidade na linha "Value:", conforme ilustrado abaixo. 


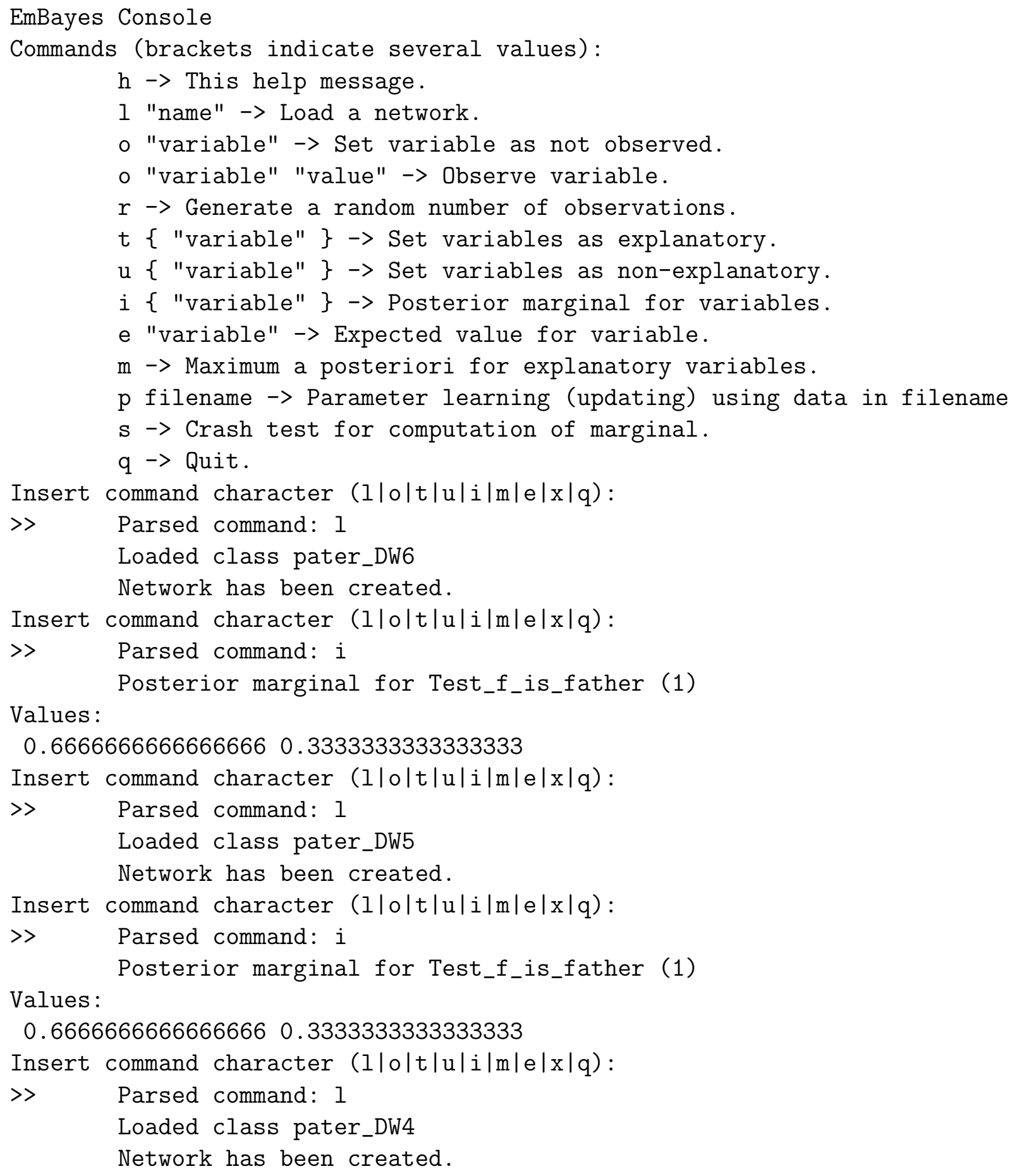




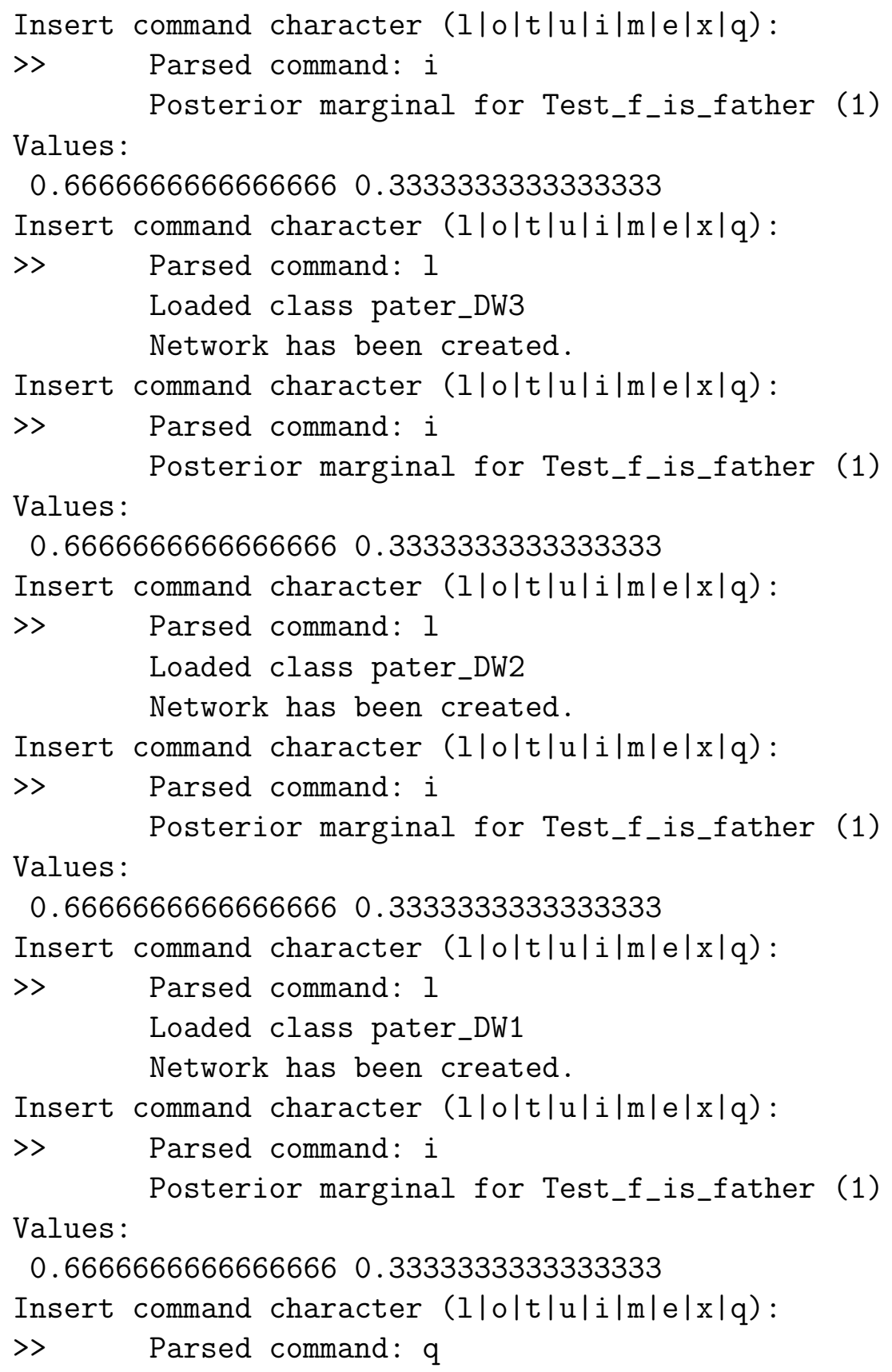

O módulo seguinte lê o arquivo cmdres.txt e calcula a probabilidade de paternidade dados todos os loci. 


\section{4 calcProb}

As probabilidades por locus são combinadas em uma probablidade "global" pelo módulo calcProb. Este módulo contém um analisador léxico que localiza o nome do locus e o valor da probabilidade e uma rotina que implementa o cálculo por odds ratio explicado no capítulo 3.

./calcProb <input file><output file>

$<$

O arquivo de entrada é "cmdres.txt" o arquivo de saída contém para cada locus a probabilidade a posteriori e a razão de verossimilhança, a quantidade de loci calculados a razão de verossimilhança considerando todos os loci e finalmente a probabilidade de paternidade a posteriori dados todos os loci.

$\begin{array}{lll}\text { DW6 } & 0.66666666666667 & 2 \\ \text { DW5 } & 0.66666666666667 & 2 \\ \text { DW4 } & 0.66666666666667 & 2 \\ \text { DW3 } & 0.66666666666667 & 2 \\ \text { DW2 } & 0.66666666666667 & 2 \\ \text { DW1 } & 0.66666666666667 & 2 \\ \text { nloci } & 6 & \\ \text { likelihood } & 64 & \\ \text { posterior } & 0.98461538461538\end{array}$

\section{5 paterdoc}

Este módulo utiliza o mesmo parser do pater, com o objetivo de documentar o heredograma. O produto final é a figura do heredograma e pode ser gerada em diversos formatos gráficos, como GIF, JPEG, PDF, entre outros. Isto é feito com o uso dos programas "fig2dev" [XFig, 2006] e "kinship" [Atkinson, 2006].

$\mathrm{O}$ arquivo-fonte é convertido pelo paterdoc em uma tabela no formato requerido pelo programa kinship. Este programa é uma biblioteca R [R-Project] da qual, neste projeto, são necessárias somente as funções que desenham heredogramas. Um comando $\mathrm{R}$ faz com que a figura seja gerada em um arquivo texto no formato XFig. Esse arquivo serve de entrada para o programa fig2dev que gera a figura nos formatos gráficos.

A chamada para paterdoc é: 
paterdoc <pater input file $>\langle$ path to $* . r\rangle\langle g / n\rangle$

generate pedigree drawings in gif format;

output file = <pater input file>.gif.

auxiliary files (intermediates): <pater input file>.kns

ped.r, <pater inputfile>.sh and <pater inputfile>.fig

$\langle\mathrm{g} / \mathrm{n}\rangle$ specifies whether or not to include genotypes in the graphics.

O arquivo de entrada é o mesmo do pater. paterdoc também escreve um script que chama seqüencialmente o pacote kinship e o fig2dev que gera o arquivo de nome $<$ pater input file $>$.gif. O formato foi fixado para GIF para facilitar a exibição através de Web-browser.

\section{6 bifdoc}

bifdoc gera um documento LaTeX contendo as tabelas de probabilidade e a figura da rede bayesiana tal como mostrada na interface do JavaBayes. O programa lê arquivos de especificação de redes bayesianas no formato BIF do JavaBayes e escreve um arquivo LaTeX e outro no formato XFig. Este arquivo é passado para o fig2dev que gera a figura no formato EPS, este arquivo já está incluído no arquivo LaTeX.

\subsection{Teste do equilíbrio de Hardy-Weinberg}

A chamada ao módulo de teste do equilíbrio de Hardy-Weinberg é:

./hwe $\$ \backslash l t \$$ hwe input file $\$ \backslash g t \$[$ path to .so and .r]

O arquivo de entrada usa um subconjunto da linguagem de definição de heredogramas:

1 marker TTDz2;

2 TTDz2.alele $=\{\mathrm{S} 10, \mathrm{~S} 12, \mathrm{~A} 14, \mathrm{r} 12, \mathrm{SX}\}$;

3 TTDz2.S10.yfreq $=\{110 @ S 10,200 @ S 12,200 @ A 14,200 @ r 12,200 @ S X\}$; 
4 TTDz2.S12.yfreq $=\{210 @ A 14,100 @ S 12,200 @ r 12,200 @ S X\}$;

5 TTDz2.A14.yfreq $=\{1200 A 14,200 @ r 12,200 @ S X\}$;

6 TTDz2.r12.yfreq $=\{100 @ r 12,200 @ S X\}$;

7 TTDz2.SX.yfreq $=\{100 @ S X\}$;

Neste arquivo é definido o marcador TTDz2 (linha 1) com 5 alelos (linha 2) e a contagem de indivíduos na amostra com determinado genótipo (linhas 3 a 7). Por exemplo, na linha 3 um dos genes é S10 e o outro é dado no vetor associativo: S10 com 100 indivíduos, S12 com 200 indivíduos e assim por diante até SX com 200 indivíduos.

hwe converte o arquivo de entrada em scripts na linguagem $\mathrm{R}$ e passa o comando para o R. Este por sua vez utiliza a implementação de Sílvio [Silvio, 2006] do FBST e apresenta o resultado em < marker>.out.

"TTDz2"

"r12" 0.98

"SX" 0.95

"S12" 0.99

"S10" 0.36

"A14" NA

"TTDz2" 0.9993

O arquivo de saída inicia com o nome do locus, em seguida para cada alelo, do menos freqüente até o mais freqüente, o valor da evidência. Por último, para loci com nove ou menos alelos, apresenta-se a evidência a favor da hipótese de equilíbrio para o teste direto.

\section{Referências}

[Cozman,2001]

COZMAN, F. G. - JavaBayes User Manual

http://www.usp.br/fgcozman/home.html 2001 University of São Paulo - Brasil

[Aho, 1986]

AHO, A. F., SETHI R., ULLMAN J. D. - Compilers Principles, Techniques and Tools 1986 - Addison-Wesley 
[R-Project $]$

[Atkinson, 2006]

[XFig, 2006]

[Silvio, 2006]
- DALGAARD PETER - Introductory Statistics with R. - Springer, 2002. ISBN 0-387-95475-9. or http://www.r-project.org

ATKINSON, B., THERNEAU T. The Kinship Package

2006 - in. R-project website (http://www.rproject.org)

- http:

www.xfig.org - XFig 3.2.4 User Manual - 2006

http://www.xfig.org

Silvio 


\section{Comentários Finais}

Nesta tese foram abordados alguns pontos do exame genético de vínculo de paternidade, mais especificamente:

- o modelo para o cálculo da probabilidade de paternidade e

- o teste do equilíbrio de Hardy-Weinberg

O primeiro por ser o problema central da análise estatística neste exame, o segundo por ser uma hipótese forte dos modelos existentes. A necessidade desta hipótese vem do fato de que os modelos são simplificações que não consideram todos os aspectos do processo biológico - neste caso, a perturbação do processo herança por fatores seletivos.

Tratar adequadamente tais fatores implica, ou resulta, em saber qual a freqüência genotípica na população no instante em que os indivíduos foram concebidos.

Neste aspecto, o modelo de referência, que usa freqüências alélicas sofre integralmente, enquanto o modelo proposto utiliza freqüências genotípicas e tira proveito disso no teste da hipótese de paternidade, embora ainda não considere fatores seletivos no processo de herança. Cabe lembrar que o modelo proposto se comporta como o de referência quando informação equivalente é fornecida a ambos.

Devido à depedência do modelo ao equilíbrio, torna-se necessário testálo. Para isto utilizou-se o FBST, conforme metodologia proposta no artigo já citado anteriormente.

Os modelos e metodologias acima foram implementados em software, o que agiliza a parte estatística do exame. Esse software pode ser operado por técnicos devidamente treinados ou entregue, como módulo fechado, a desenvolvedores de interfaces que tornarão esta ferramenta ainda mais amigável. 